\title{
FINANCING EDUCATION AND THE EFFECT OF THE TAX LAWS
}

\author{
Julian H. Levi*
}

Reconstitution of the Ways and Means Committee in the Ninety-fourth Congress appears to assure continued discussion and attack upon the charitable deduction provisions of the United States Internal Revenue Code. Thus, review of salient criticisms of the charitable deduction is in order. In particular, an assessment of the effect of these provisions on financing higher education would seem to be especially suitable.

Positions of the contestants were sharply delineated in proceedings throughout the Ninety-third Congress, and the position of charities, particularly higher education, has become clear. Evidence is accumulating that the fears of colleges, universities, and other charities that they may sustain substantial losses of donations if the proposed changes are enacted are justified. Finally, since the continued independence of American higher education from governmental financial support is at issue, consideration of the philosophic rationale of independent private choice and pluralism is appropriate.

\section{I}

Critics of the existing law with respect to charitable contributions propound several arguments. First, they contend that recognition of a deduction, and consequent relief from an otherwise unmitigated income tax burden, violates "tax logic" and "tax equity" and constitutes an undemocratic expenditure of government funds at the discretion and decision of private individuals. Indeed, the Fiscal Year 1976 Budget of the United States Government contains special analyses dealing with "tax expenditures" which are defined as "those revenue losses attributable to provisions of the federal tax laws which allow special exclusion, exemption, or deduction from gross income, or which provide a special credit, or a preferential rate of tax, or a deferral of tax liability." 1

\footnotetext{
* Professor of Urban Studies, Division of Social Sciences, University of Chicago. The author most gratefully acknowledges the invaluable assistance of Mr. Charles Lee, Executive Director of the Committee for Full Funding of Educational Programs; Mr. Sheldon Steinbach, Staff Counsel and Assistant Director, Office of Governmental Relations; Ms. Patricia Smith, Policy Associate of the American Council on Education; and Ms. Carol T. Rone.

1. Congressional Budget and Improvement Control Act of 1974, §3(a)(3), 31 U.S.C.A. $\$ 1302$ (Supp. 1975).
} 
Special analysis F-1 is stated to be the Tax Expenditure Budget Estimate by function and includes: ${ }^{2}$

\begin{tabular}{llllllll} 
& \multicolumn{3}{c}{ Corporations } & \multicolumn{3}{c}{ Individuals } \\
$\begin{array}{l}\text { Description } \\
\text { Deductibility of con- }\end{array}$ & $\underline{1974}$ & $\underline{1975}$ & $\underline{1976}$ & & $\underline{1974}$ & $\underline{1975}$ & $\underline{1976}$ \\
$\begin{array}{c}\text { tributions to edu- } \\
\text { cational institutions }\end{array}$ & 155 & 160 & 155 & 355 & 405 & 435 \\
$\begin{array}{c}\text { Deductibility of chari- } \\
\text { table contributions } \\
\text { (other than educa- } \\
\text { tion) }\end{array}$ & 290 & 295 & 285 & 3,820 & 4,485 & 4,480 \\
(in millions of dollars) & & & & & & &
\end{tabular}

Second, critics argue that wealthy taxpayers secure an unconscionable advantage in that their charitable deductions will be applied to income that is subject to higher bracket tax rates. Thus, the "real" cost of a hundred dollar contribution made by a taxpayer in the 70 per cent bracket is thirty dollars, whereas the identical gift made by a taxpayer in the 14 per cent bracket will "cost" him eighty-six dollars. ${ }^{3}$

Third, they are sharply critical of the "loophole" available to the donor of appreciated property who, under existing law, may claim a charitable deduction equal to the fair market value of the donated property without regard to the amount of his cost or tax basis while at the same time no tax is assessed upon such appreciation in value. ${ }^{4}$

To correct these alleged inequities, those critical of the existing tax laws propose a variety of statutory changes which include elimination of the charitable deduction altogether (sometimes coupled with a proposal to substitute a matching grant system), ${ }^{5}$ identical treatment of all charitable deductions by means of a fixed credit against tax rather than by deduction from gross income (under this arrangement the taxpayer, regardless of income, would obtain a nonrefundable credit against tax), establishment of a floor under deductions akin to that provided with respect to medical expenses, and allowance of the charitable deduction only to the extent of the ratio between the taxpayer's "taxed" and "untaxed" income. Reform directed at gifts of appreciated proper-

2. Budget of the U.S. Government, Fiscal Year 1976, Special Analyses 108 , 109 (1975).

3. S. Surrey, Pathways to Tax Reform: The Concept of Tax Expenditures 226-27 (1973).

4. Id.

5. Id. at 229-30. The proposal to substitute matching grants for tax deductions could well present insuperable constitutional obstacles to support of religious institutions of education. See Bitker, Charitable Contributions: Tax Deductions of Matching Grants, 28 TAx L. Rev. 37, $40-43$ (1972). See also McDaniel, An Alternative to the Federal Income Tax Deduction in Support of Private Philanthropy, in Tax Institute of America, Tax Impacts on Philanthropy 171 (1972); McDaniel, Federal Matching Grants for Charitable Contribution: A Substitute for the Income Tax Deduction, 27 TAX L. REv. 377 (1972). 
ty proposes either to treat the donation as a realization of the appreciation to be included in gross income, or to restrict the amount of the deduction to the basis of the donated property.

The view that a deduction for a charitable contribution represents a form of government spending called a "tax expenditure" has gained substantial acceptance in recent years as a result of the advocacy of Stanley Surrey ${ }^{6}$ and, as indicated, is now a term included in the official United States budget. With increasing pressures to reduce federal "spending," its acceptance probably presents the clearest danger that the deduction for charitable contributions may be further weakened by future legislation. This analysis, however, has substantial shortcomings and rests on a form of logic that implies a financial obligation of citizens to the United States which is totally at odds with our fundamental concepts of freedom.

Irving Kristol with customary incisiveness has noted the peculiarity of the logic leading to the concept of a "tax expenditure."

Many economists and tax experts-Stanley Surrey, most notably-nevertheless do favor subsidies rather than tax incentives, and argue persuasively for them. But in the course of making these arguments, a very interesting rhetorical transformation takes place. They begin to think and talk as if the basic decision to subsidize had already been made-only, the subsidies are now incarnated in the tax system rather than in positive legislation. So they come quickly to refer to all exemptions and allowances in our tax laws as "tax subsidies" or even "tax expenditures." But note what happens when you make this assumption and start using such terms. Yow are implicitly asserting that all income coiered by the general proisisions of the tax laws belongs of right to the government, and that what the government decides, by exemption or qualification, not to collect in taxes constitutes a subsidy. Whereas a subsidy used to mean a governmental expenditure for a certain purpose, it now acquires quite another meaning-i.e., a generous decision by government not to take your money.

When a man makes a tax-deductible gift to charity, whose money has he given away? Traditionally, it has been thought that he gives away his own money, and that the tax deduction exists only to encourage him to give away his own money for such a purpose. Today, however, one hears it commonly

6. S. Surrey, supra note 3 , at $2,6-14$.

7. Kristol, Taxes, Poverty, and Equality, 37 PuB. INTERest 3, 14-15 (Fall 1974) (emphasis in original). Professor Boris Bittker has also leveled a serious attack on the concept of tax expenditures, noting that there is nothing sacrosanct about any one person's judgment as to the amount of tax owed to the government.

There is no surer way to discredit scholarship than to clain that value judgments can be plucked out of a definition, or even out of an expert. To acknowledge candidly that expertise has its limits is not a counsel of despair, nor does it abdicate to the forces of darkness. Experts can point out problems, offer alternative solutions, illuminate the consequences of choosing one route rather than another, and support their own preferences with argument and rhetoric. At bottom, however, every tax structure, whether on the books or projected, is an assemblage of value judgments on scores of issues that could plausibly have been decided differently. To bestow the label "correct" on any of these human creations is to misuse the term.

Bittker, The Tax Expenditure Budget-A Reply to Professors Surrey and Hellmuth, 22 NAT'L TAx J. 538 , 542 (1969). 
said that he has only in part given away his own money-in actuality, he has also given away some "public" money. This "public" money consists of that sum which, were no such deductions permitted by law, he would have to pay in taxes. It is then said-indeed, it is now a cliche-that the object of his philanthropy (a museum, say) is "in effect" being subsidized by public monies.

What we are talking about here is no slight terminological quibble. At issue is a basic principle of social and political philosophy-the principle that used to be called "private property." The conversion of tax incentives into "tax subsidies" or "tax expenditures" means that "in effect" a substantial part of everyone's income really belongs to the government-only the government, when it generously or foolishly refrains from taxing it away, tolerates our possession and use of it. To put it another way, when you start talking glibly of some $\$ 70$ billion of legal deductions and allowances as "tax subsidies," you have already in imagination socialized that amount of personal and corporate incone.

The implicit assumption in the concept of "tax expenditures," that citizens owe their incomes to the United States, is reminiscent of the assumptions upon which feudal societies were organized. Consider, for example, how Harry A. Bigelow described the system of land holding in England during the time of Henry II: ${ }^{8}$

It may, roughly, be compared to a pyranid: At the summit of the pyramid was the king, who was, in legal theory, the owner of all land in England. Immediately under him were the great lords of the kingdom, holding the large tracts of land in the manner already mentioned. These tenants immediately under the king later received the name of "tenants in capite." Under the tenants in capite were various grades of intermediate or mesne tenants, and at the bottom of the pyramid may be said to be the tenants who were in actual occupation of the land, either personally or by their servants. . . Thus it may be said that, except for the highest and lowest grades, each person occupied a double relation. With respect to the person under whom he was holding he was a tenant, owing fealty and faith and feudal services, and entitled to receive protection from his lord.

Assuming such a society, a "tax expenditure" budget is inescapable. F.W. Maitland's classic, The History of a Cambridgeshire Manor, demonstrates the point. Maitland had before him "a splendid line of court and account rolls which, though there were some gaps in it, stretched from Edward I to Henry VII." Thus he was able, as he put it, "to lay before the readers . . . a fairly continuous history of a particular English manor during the later Middle Ages ...."9 The Manor of Wilberton formed part of the ancient estates of the Church of Ely. The court rolls maintained by the Bishop, the bailiff and reeve, account for the relations and services described by Bigelow. First, small money rents were collected. Second, collections accrue from particular transactions (comparable to an exise tax) including excuse from attendance at court, where the freeholder would "owe a heriot (best beast, or $32 \mathrm{~d}$.), a fine for marrying

8. H. Bigelow, Cases and Materials on Rights in Land 2, 3 (3d ed. 1945).

9. 2 The Collected Papers of Frederick William Maitland 366-406 (H. Fisher ed. 1911 ). 
their daughters $(32 \mathrm{~d}$.), leyrwite and tallage; the gersuma, or fine for marrying a daughter, is mentioned in the earlier extent."10 Third, tenants were required to provide labor described as "works." The assigned value of such works depended not only on the character of the work performed, but the season of the year.

Some works were excused because of public services performed by the reeve, the reaper, or the smith. Some works would be excused on account of festivals (perhaps an early form of the charitable deduction calculated on a tax expenditure basis). At any rate, the reeve in one of his accounts calculating upon a year running from Michaelmas to Michaelmas in the last six years of Edward II's reign produced the following tax expenditure budget, excusing performance of works in some cases (a tax subsidy), and assigning value (a tax expenditure) in others: ${ }^{11}$

\begin{tabular}{|c|c|}
\hline Excused to reeve, reaper, smith & 58 \\
\hline Excused in respect of a cottary let at a rent & $7-1 / 2$ \\
\hline Excused on account of festivals & 58 \\
\hline Sold & $246 \cdot 1 / 2$ \\
\hline $\begin{array}{l}\text { Reaping, binding, and stacking } 128 \text { acres at } \\
\text { two works per acre }\end{array}$ & 256 \\
\hline Carrying & 96 \\
\hline Garnering ${ }^{1}$ & 22 \\
\hline Stacking pease & 10 \\
\hline Carrying dung & 58 \\
\hline & 812 \\
\hline
\end{tabular}

${ }^{1}$ In bladis mayand in grangia. The word mayare is new to me. (See Baxter, Medieval Latin. Word-List, s.v. meia.)

The second criticism of deductions for charitable contributions, that wealthy taxpayers are benefited more than low income taxpayers, is dependent on the "tax expenditure" concept, but it also ignores some of the rationale underlying the progressive rates system as well as some basic differences between charitable contributions and other types of expenditures. Progressive rates of taxation inherently apply unequally in the treatment of income dollars at various brackets. Thus, it is hardly novel that the higher the bracket the greater the dollar value of the deduction in that classification. This observation can, of course, be made as to any allowable deduction. ${ }^{12}$ However, progressive rates are not easily defended. Historically, they have often been defended on the grounds that the high-income taxpayer is "hurt" no more by a high rate than is a low-income taxpayer by a low rate because of the declining marginal utility of the dollar as incomes increase. ${ }^{13}$ If that is true, then the high-income

10. Id. at $367-68$.

11. Id. at 375 .

12. Andrews, Personal Deductions in an Ideal Income Tax, 86 Harv. L. Rev. 309, 345 (1972).

13. W. Blum \& H. Kalven, The Uneasy Case for Progressive Taxation (1953). 
taxpayer is likewise not benefited more by a deduction affecting income at the top of the marginal rate brackets.

Furthermore, the act of voluntary giving is different from transactions and acts giving rise to other tax deductions. The taxpayer's gift to charity is not an expenditure required or calculated to produce income. Payment of local and state taxes is compelled by legal and even, in most cases, by criminal sanction. Payment of medical expenses or interest charges ordinarily are not at the option of the taxpayer. In contrast the decision any taxpayer makes about his gift to charity is not mandated by any legal penalty or economic sanction.

A substantial body of law distinguishes the charitable gift and rebuts the contention sometimes asserted that charitable contributions "represent discretionary spending much like any other personal expenditure." of the Internal Revenue Code in allowing and defining the charitable deduction requires a contribution or gift to be to or for the use of an eligible donee with the condition as to each class of donee that "no part of the net earnings... inures to the benefit of any private shareholder or individual."15

Courts in income tax matters have distinguished the charitable gift from the personal or family expenditure. ${ }^{16}$ In DeJong $\%$. Commissioner, taxpayers claimed a charitable deduction of $\$ 1,075$ paid by them to a private non-profit school attended by their children. ${ }^{17}$ The court approved the determination of the Tax Court that at least four hundred dollars of the alleged gift was in fact payment of tuition and a family expenditure: ${ }^{18}$

The section allows as a deduction any charitable contribution (as defined), payment of which is made within the taxable year. As defined in Subsection (c), the term "charitable contribution" means a contribution or gift to or for the use of certain types of organizations organized and operated for certain specified purposes and having certain specified characteristics. The Society is admittedly one such organization and its tax-exempt status is not an issue. The section, however, does not further define the terms "contribution" and "gift." The Tax Court stated that as used in the section, the terms are synonymous.... We have found nothing which indicates otherwise.

Commissioner of Internal Revenue $\vartheta$. Duberstein summarizes the applicable case law: ${ }^{19}$

The course of decision here makes it plain that the statute does not use the term "gift" in the common-law sense, but in a more colloquial sense. This Court has indicated that a voluntary executed transfer of his property by one to another, without any consideration or compensation therefor, though a common-law gift, is not necessarily a "gift" within the meaning of the statute. For the Court has shown that the mere absence of a legal or moral obligation

14. 26 U.S.C. $\S 170(\mathrm{c})$.

15. $I d$.

16. See, e.g., Singer Co. v. United States, 449 F.2d 413 (Ct. Cl. 1971).

17. 309 F.2d 373 (9th Cir. 1962).

18. Id. at 376 .

19. 363 U.S. 278, 285-86 (1960) (crtations omitted). 
to make such a payment does not establish that is it a gift. . . And, importantly, if the payment proceeds primarily from . . . "the incentive of anticipated benefit" of an economic nature, . . it is not a gift. And, conversely, "[w]here the payment is in return for services rendered, it is irrelevant that the donor derives no economic benefit from it." . . . A gift in the statutory sense, on the other hand, proceeds from a "detached and disinterested generosity" . . . "out of affection, respect, admiration, charity of like impulses." ... And in this regard, the most critical consideration, as the Court was agreed in the leading case here, is the transferor's "intention." . . "What controls is the intention with which payment, however voluntary, has been made."

Although some commentators would complain about Duberstein, the Court itself anticipated that reaction by noting that the conclusion in that case "may not satisfy an academic desire for tidiness, symmetry and precision in this area." ${ }^{\prime \prime}$ These considerations could well explain the determination of Congress not to treat gifts to a public charity as a tax preference for purposes of the minimum tax imposed by section 56 of the Internal Revenue Code of $1954 .^{21}$

The third criticism, involving the loss of revenue from gifts of appreciated property to charity, is largely overstated because it ignores all the effects that a change in the law would produce and calculates revenue loss on the assumption that donors would continue to act in the same way as they presently do. Thus, claims of "profit" achieved by donors through gifts of appreciated property to charities are misleading. The calculation assumes the excused capital gains tax to be profit. The donor's position is characterized as "being obligated to sell" and his financial status as including "an inherent potential liability" of capital gains tax on the appreciation. ${ }^{22}$

Appreciation in value of a capital asset, however, does not give rise to tax liability for capital gain unless and until that appreciation is realized.$^{23}$ Under present law, for example, appreciation is not realized by transfer at death. Thus "this exemption-a zero rate of tax on the gain on such assets-obviously presents an impediment to increasing the tax rate on gains realized during life, since the attraction of a zero rate at death would cause owners to hesitate selling appreciated assets." 24

This speculation has been verified: ${ }^{25}$

Capital gains realized from all sources for tax purposes are a small fraction of total accrued capital gains estimated for corporate shares alone. The limited data available suggest that the accrued capital gains on more than half of corporate shares go permanently unrealized because of the regulations governing their treatment on gift or bequest, and that those assets that are sold are held for periods of several years on the average. The mere lapse of

20. Id. at 290 .

21. 115 Cong. Rec. 37, 497-504 (1969).

22. S. SURREY, supra note 3 , at 374-75.

23. Id. at 197 .

24. Id. at 196 .

25. The Taxation of Income From Capital 38 (A. Harberger \& M. Bailey eds. 1969). 
time between sales reduces the ratio of realizations to accruals, and similarly reduces the expected value of the capital gains tax.

Under such circumstances, a balance sheet of a donor-taxpayer carrying a liability for tax on unrealized appreciation is unwarranted. ${ }^{26}$ Except in the unusual case where the donor is under compulsion to sell (such as a donor holding a preferred stock called for redemption), the choices before a potential donor are to sell the property, retain it, or donate it. These are his realistic alternatives.

The Ways and Means Committee of the Ninety-third Congress considered changes in treatment of gifts of appreciated property by altering provisions of the minimum tax law, proposing that while cash contributions to charity would be permitted as deductions from "economic income," contributions of property would be limited to the basis of the donor. ${ }^{27}$ The Committee staff calculated that the effect of this change would be to produce sixty-five million dollars in additional tax revenue while at the same time charitable contributions would be reduced by more than three hundred million dollars. ${ }^{28}$ Treasury estimates thereafter changed from day to day by as much as one hundred million dollars of additional predicted contribution losses. The Treasury admitted, at one point, that information available from analyses of income tax returns did not distinguish between gifts to charity of property as compared to gifts of money, and that the estimates were formed by "eyeball examination" of something less than one hundred returns. ${ }^{29}$

Finally on July 28, 1975 the Treasury abandoned the point altogether. Secretary Simon in testimony before the Ways and Means Committee stated: ${ }^{30}$

The committee provisions adopted the basic concept of MTI. One of the controversial issues was the treatment of charitable deductions. Under the original Treasury proposals, charitable deductions would have been included like any other personal deductions and exclusions to eliminate more than half of a taxpayer's "economic" income. After considerable discussion, the committee decided to put charitable deductions entirely outside the scope of the provision, which meant that taxpayers with very large charitable deductions would still be able, under certain circumstances, to eliminate all or virtually all of their taxable income. While the Treasury opposed that modification last year, we are now persuaded, in view of the dire financial position in which inflation has left so many private charities, that the committee decision was appropriate and we support it.

26. Compare S. SuRREY, supra note 3 , at 374-75.

27. Committee on Ways and Means, Tax Reform Legislation, Minimum Tax, Release No. 21. (August 2, 1974).

28. Letter from John F. Morse, Director, Office of Governmental Relations, American Council on Education to Ernest S. Christian, Tax Legislation Counsel, Department of the Treasury, Sept. 12, 1974.

29. Id.

30. Hearings on the Subject of Reform of the House Comm. on Ways and Means, 94th Cong., 2d Sess., pt. I, at $10(1975)$. 
President Ford has reiterated the position: ${ }^{31}$

I approve and support the principle of voluntary giving to help finance higher education .... I I will oppose any legislative proposal which discourages such support, including those which would limit charitable deductions, disallow the full value of appreciated assets, or exclude state tax deductions.

Be this as it may, the importance of voluntary support for higher education is clear. Since 1954 the Council for Financial Aid to Education (C.F.A.E.) has published statistics covering voluntary support of American colleges and universities. $^{32}$

TABLE I

Histohcal Recond - Colleges and Universities

\begin{tabular}{|c|c|c|c|c|c|}
\hline Year & $\begin{array}{l}\text { Insti- } \\
\text { tutions }\end{array}$ & $\begin{array}{c}\text { Total Support } \\
\text { Reported }\end{array}$ & \& Change & $\begin{array}{l}\text { Average per } \\
\text { Institution }\end{array}$ & \% Change \\
\hline $1954-55$ & 728 & $\$ 289,541,520$ & & $\$ 397,722$ & \\
\hline $1956-57$ & 904 & $738,118,105^{\circ}$ & +154.9 & 816,502 & +105.3 \\
\hline $1958-59$ & 1,071 & $626,583,562$ & -15.1 & 585,045 & -28.3 \\
\hline $1960-61$ & 1,032 & $802,985,596$ & +28.1 & 778,087 & +33.0 \\
\hline $1962-63$ & 1,036 & $911,362,364$ & +13.5 & 879,693 & $\begin{array}{r}13.1 \\
+\quad 13\end{array}$ \\
\hline $1964-65$ & 1,064 & $1,244,815,734$ & +36.6 & $1,169,939$ & +33.0 \\
\hline $1965-66$ & 1,033 & $1,229,794,118$ & $-\quad 1.2$ & $1,190,507$ & $+\quad 1.8$ \\
\hline $1966-67$ & 1,042 & $1,269,968,536$ & $+\quad 3.3$ & $1,218,779$ & +2.4 \\
\hline $1967-68$ & 1,043 & $1,371,556,894$ & +8.0 & $1,315,011$ & +7.9 \\
\hline $1968-69$ & 1,013 & $1,460,877,899$ & +6.5 & $1,442,130$ & $\begin{array}{r}+ \\
+\quad 9.7\end{array}$ \\
\hline $1969-70$ & 1,045 & $1,472,308,580$ & $\begin{array}{r}0.8 \\
+\quad 0\end{array}$ & $1,408,907$ & -2.3 \\
\hline $1970-71$ & 1,080 & $1,503,837,288$ & $\begin{array}{l}1.1 \\
+\quad 2.1\end{array}$ & $1,392,441$ & $-\quad 1.2$ \\
\hline $1971-72$ & 1,093 & $1,646,606,573$ & $\begin{array}{r}+9.5 \\
+\quad 1\end{array}$ & $1,506,501$ & +8.2 \\
\hline $1972-73$ & 1,020 & $1,750,988,649$ & $\begin{array}{r}1 \\
+\quad 6.3\end{array}$ & $1,716,655$ & +13.9 \\
\hline
\end{tabular}

- Including $\$ 199,522,710$ in non-recurring faculty salary endowment grants from The Ford Foundation.

Source: Council for Financial Aid to Education, Voluntary Support of Education $1973-74$, at $59(1975)$.

C.F.A.E. has gathered this data by questionnaire and over the years a high degree of response has been obtained. The most recent report (1973-74) invited the responses of 2811 senior colleges and universities, junior colleges, and private pre-college schools. Thirteen hundred three completed and tabulated questionnaires were received. ${ }^{33}$ C.F.A.E. verified total voluntary support

31. Chronicle of Higher Ed., Sept. 29, 1975, at 7.

32. Council for Financial Aid to Education, Voluntary Support of Education 1973 1974 , at 59 (1975) [hereinafter cited as C.F.A.E. 1973-1974].

33. Id. 
received by institutions of higher education in $1972-73$ at $\$ 1,750,988,649$. (Making allowance for nonparticipants, the Council estimated the gross figure at $\$ 2,240$ billion.) The Council further found this support distributed among the various groups of institutions, as seen in Table II. ${ }^{34}$ More recently, the Commission on Private Philanthropy commissioned a series of economic studies dealing with various facets of support of the American charitable university. ${ }^{35}$

\section{TABLE II}

Voluntahy Support of Higher Education, By Type of Institution

(including percentage of Grand Total, and average per institution) (dollar totals and averages in thousands)

\begin{tabular}{lc}
\hline \multicolumn{1}{c}{ Group $^{2}$} & $1972-1973$ \\
\hline Major Private Universities & $\$ 709,409 \quad(40.5 \%)$ \\
Private Coeducational Colleges & $(65)$ Av. $\$ 10,913$ \\
& $442,598 \quad(25.3 \%)$ \\
Public Institutions & $(433)$ Av. $\$ 1,022$ \\
& $383,276 \quad(21.9 \%)$ \\
Professional \& Specialized Schools & $(217)$ Av. $\$ 1,766$ \\
Private Women's Colleges & $106,413 \quad(6.1 \%)$ \\
Private Men's Colleges & $(71)$ Av. $\$ 1,498$ \\
& $61,567 \quad(3.5 \%)$ \\
Junior Colleges & $(85)$ Av. $\$ 724$ \\
& $(12,437 \quad(1.3 \%)$ \\
Grand Total & 25,602 \\
& $(135)$ Av. $\$ 187$ \\
\end{tabular}

'In every Survey, each institution is classified in the category appropriate to its status in that year. Since the status of many institutions has changed over the years, the data by category is not strictly comparable from one Survey to another. See Page 6 for a comparison of 1971-72 and 1972-73 data on an adjusted basis.

Source: Council for Financial Aid to Education, Voluntary Support of Education 1973-74, at 65 (1975).

The C.F.A.E. also listed the twenty institutions receiving the highest totals of voluntary support for $1973-74 .^{36}$

34. C.F.A.E. 1973-1974, at 65.

35. Comm'n on Private Philanthropy and Public Needs, giving in america: Toward a STRONGer Voluntary Sector (1975).

36. C.F.A.E. 1973-1974, at 8. 
TABLE III

Institutions Receiving Highest Totals of Voluntary Support 1973-74

\begin{tabular}{|c|c|c|c|}
\hline Institution & $\begin{array}{c}\text { Total } \\
\text { Support }\end{array}$ & Institution & $\begin{array}{c}\text { Total } \\
\text { Support }\end{array}$ \\
\hline Harvard University & $\$ 57,154,814$ & New York University & $\$ 26,929,449$ \\
\hline Stanford University & $46,513,140$ & Wisconsin, University of & $22,650,851$ \\
\hline California, University of- & & Vanderbilt University & $22,209,859$ \\
\hline System & $44,329,041$ & Princeton University & $22,136,112$ \\
\hline Yale University & $32,185,329$ & Michigan, University of & $21,910,826$ \\
\hline Cornell University & $30,614,561$ & M.I.T. & $21,663,402$ \\
\hline Northwestern University & $30,306,661$ & Minnesota, University of & $20,392,202$ \\
\hline Pennsylvania, University of & $28,896,812$ & Southern California, & \\
\hline Chicago, University of & $28,673,133$ & University of & $18,818,191$ \\
\hline Emory University & $27,440,470$ & Case Western Reserve & \\
\hline \multirow[t]{2}{*}{ Columbia University } & $27,141,396$ & University & $18,170,380$ \\
\hline & & Dartmouth College & $16,259,044$ \\
\hline
\end{tabular}

Source: Council fon Financial Aid to Education, Voluntany Suppont of Education 1973-74, at 8 (1975).

The National Association of State Universities and Land Grant Colleges on August 6, 1974 listed the ten public state universities and land grant colleges receiving the largest amount of private support as follows: ${ }^{37}$
Univ. of California
Cornell Univ.
Univ. of Wisconsin
Univ. of Michigan
Mass. Inst. of Tech.
Univ. of Minnesota
Univ. of Illinois
Univ. of North Carolina
Indiana Univ.
Univ. of Calif., Berkeley
$\$ 44,329,041$
$30,614,561$
$23,542,708$
$21,910,826$
$21,663,402$
$20,392,202$
$14,223,173$
$13,691,506$
$13,034,363$
$11,120,503$

The National Association noted that three universities which did not participate in the study had benefited greatly from private support in the preceding 1971-72 year. The University of Texas received thirty-three million dollars and the University of Nebraska, Rutgers, and the City University of New York received combined private support of more than $\$ 16.5$ million. The Association further noted that twelve of its members received more than 10 million dollars in private support in 1972-73 and 67 member institutions received more than one million dollars in private support. Thus, voluntary support is important to all segments of higher education, public as well as private institutions. It is a grievous error to assume that voluntary support is important for or restricted to only a few "elitest institutions."

37. National Ass'n of State Universities and Land Grant Colleges 4 (Fyi Circular No. 193, 1974). 
Moreover, those institutions thoughtlessly referred to as "elitest" are the very institutions which, in the dark days of oppression maintained academic freedom, have been recently in the vanguard of the emancipation of students from archaic rules, and have provided throughout their history the competitive market place for ideas that have contributed so much to the improvement of American society.

The Chronicle of Higher Education in 1974 provides the most recent available statistics on the number of minority students enrolled in undergraduate and graduate departments of American public and private colleges and universities. $^{38}$ For Fall 1972, total graduate enrollment was 398,935 , of which number 36,500 were minority students. This component divided between the public universities at 8.61 per cent and the private universities at 10.24 per cent of all enrollment. At that time total undergraduate enrollment was 5,235,310, of which 638,176 were minority students. This component divided between the public universities at 12.71 per cent and the private universities at 10.52 per cent of all enrollment. Thus, the private sector of higher education served a total of 145,721 minority graduate and undergraduate students. The loss or diminution of voluntary support will in all likelihood not destroy the larger institutions. It could, however, lower excellence to mediocrity. The smaller, less prestigious institutions could well be destroyed.

As exemplified by Table IV, the C.F.A.E. also described the sources of voluntary support for colleges and universities in the 1972-73 and 1973-74 years. ${ }^{39}$

TABLE IV

Total Suppont By Source

All Colleges and Universities Reporting (000 omitted)

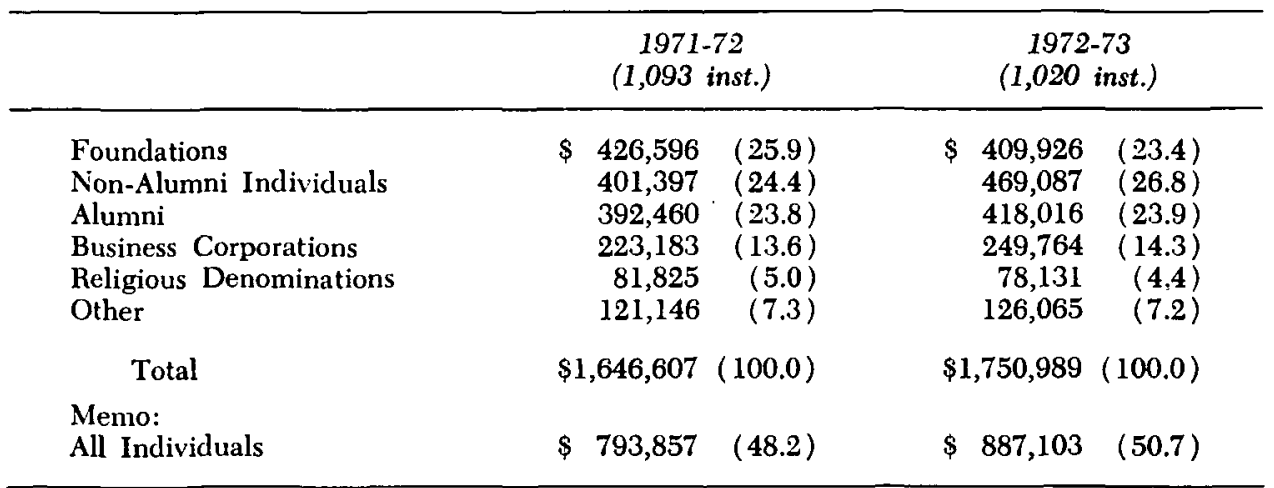

Source: Council for financial Aid to Education, Voluntaly Suppont of Education 1973-74, at 9 (1975).

38. Chronicle of Higher Ed., Nov. 11, 1974, at 9-12.

39. C.F.A.E. 1973-1974, at 9. 
In 1972-73, 51.4 per cent of all gifts were received from non-alumni and alumni individuals. However, in 1973-7441

Total support received from individual donors, alumni and non-alumni alike, decreased by $6.4 \%$ was compared to $1972-73$. The amounts indicated include support received as bequests, and this form of support increased by $4.4 \%$ in 1973-74. This implies that other forms of individual support decreased by $10.8 \%$ between $1972-73$ and $1973-74$. Virtually all of this decrease is attributable to a drop in support for capital purposes; individual gifts for this purpose decreased 9.2\% while individual support for current operations decreased only $1.9 \%$. A very large share of the decline in capital gifts was due to a $29.1 \%$ drop in the reported level of deferred giving (life income contracts, charitable remainder annuity trusts and unitrusts, etc.). Other gifts by living donors showed a decrease of $8.1 \%$ in $1973-74$.

Table $\mathrm{V}$ shows that the Council was able to analyze total support by purpose. $^{41}$

Although there were significant shifts in the relative importance of current and capital gifts among the various classes of colleges and universities and among the donor groups, the basic patterns were unchanged. Current support tends to be dominant in the voluntary support of public institutions, while capital support has generally been relatively large for private colleges and universities. Individual donors invariably give more for capital purposes, while foundations, corporations, religious denominations, and other groups and sources favor operating support over capital gifts.

TABLE V

Total Support by Purpose

All Colleges and Universities Reporting (000 omitted)

\begin{tabular}{lrrrrrr}
\hline & \multicolumn{2}{c}{$\begin{array}{c}1971-72 \\
(1,093\end{array}$} & \multicolumn{2}{c}{$\begin{array}{c}1972-73 \\
(1,020\end{array}$} & inst. $)$ & \% Change \\
\hline Unrestricted & $\$ 552,652$ & $(33.6)$ & $\$ 594,542$ & $(34.0)$ & +7.6 \\
Physical Plant & 322,577 & $(19.6)$ & & 322,830 & $(18.4)$ & +0.1 \\
Research & 210,565 & $(12.8)$ & 228,447 & $(13.0)$ & +8.5 \\
Student Aid & 214,741 & $(13.0)$ & 251,466 & $(14.4)$ & +17.1 \\
Faculty Compensation & 80,993 & $(4.9)$ & 88,901 & $(5.1)$ & + + \\
Other & 265,079 & $(16.1)$ & 264,802 & $(15.1)$ & -0.1 \\
\multicolumn{1}{c}{ Total } & $\$ 1,646,607$ & $(100.0)$ & $\$ 1,750,989$ & $(100.0)$ & +6.3 \\
Current & $\$ 877,687$ & $(53.3)$ & $\$ 929,115$ & $(53.1)$ & +5.9 \\
Capital & $\$ 768,920$ & $(46.7)$ & $\$ 821,874$ & $(46.9)$ & +6.9 \\
\hline
\end{tabular}

Source: Council fon Financial Aid to Education, Voluntany Support of Education 1973-74, at 11 (1975).

40. Id.

41. C.F.A.E. 1973-1974, at 11 . 


\section{C.F.A.E. also found: ${ }^{42}$}

The shift from capital giving to support for current operations was the result of decreases in support for capital purposes by foundations and individuals, alumni and non-alumni alike; there were contrary shifts on the part of corporations, religious denominations, and other donors. For the first time, the private colleges and universities as a group reported slightly more support for current operations than for capital purposes. At the same time, current support received by public institutions rose to $73.5 \%$ of their total, the highest proportion on record.

Unrestricted giving continued to account for one-third of total voluntary support, although there was a $2.5 \%$ decline in such gifts in 1973-74. Percentagewise, there were significant decreases in support for student aid purposes and for physical plant and a small drop in gifts for research. For the second year in a row, support earmarked for faculty compensation gained significantly, and for 1973-74 the increase amounted to $20.9 \%$. Almost half of the increase in support for this purpose came from non-alumni individuals, and virtually all of this gain was reported by major private universities and private coeducational colleges.

\section{TABLE VI}

Total Support for Current and Capital Purposes (1973-74)

\begin{tabular}{|c|c|c|c|c|}
\hline By Type of Institution & $\begin{array}{l}\text { Current O } \\
1971-72 \\
\quad \text { in per }\end{array}$ & $\begin{array}{l}\text { perations } \\
1972-73 \\
\text { cent })\end{array}$ & $\begin{array}{c}\text { Capital } P \\
1971-72 \\
\quad \text { (in per }\end{array}$ & $\begin{array}{l}\text { urposes } \\
1972-73 \\
\text { cent })\end{array}$ \\
\hline Major Private Universities & 50.2 & 51.7 & 49.8 & 48.3 \\
\hline Private Men's Colleges & 37.2 & 36.6 & 62.8 & 63.4 \\
\hline Private Women's Colleges & 42.5 & 47.0 & 57.5 & 53.0 \\
\hline Private Coeducational Colleges & 47.1 & 44.8 & 52.9 & $\mathbf{5 5 . 2}$ \\
\hline Professional \& Specialized Schools & 53.5 & 50.0 & 46.5 & 50.0 \\
\hline Public Institutions & 69.1 & 68.1 & 30.9 & 31.9 \\
\hline Junior Colleges & 59.9 & 49.6 & 40.1 & 50.4 \\
\hline Private Secondary \& Elementary Schools & 33.0 & 28.3 & 67.0 & 71.7 \\
\hline \multirow[b]{2}{*}{ By Source } & \multirow{2}{*}{\multicolumn{2}{|c|}{$\begin{array}{l}\text { Current Operations } \\
1971-72 \quad 1972-73 \\
\quad(\text { in per cent })\end{array}$}} & \multirow{2}{*}{\multicolumn{2}{|c|}{$\begin{array}{l}\text { Capital Purposes } \\
1971-72 \quad 1972-73 \\
\text { (in per cent) }\end{array}$}} \\
\hline & & & & \\
\hline Foundations & 56.2 & 53.3 & 43.8 & 46.7 \\
\hline Non-Alumni Individuals & 35.4 & 35.4 & 64.6 & 64.6 \\
\hline Alumni & 38.2 & 41.1 & 61.8 & 58.9 \\
\hline Corporations & 74.5 & 72.8 & 25.5 & 27.2 \\
\hline Religious Denominations & 83.9 & 84.7 & 16.1 & 15.3 \\
\hline Other Groups and Sources & 83.9 & 83.1 & 16.1 & 16.9 \\
\hline
\end{tabular}

Source: Council for Financial Aid to Education, Voluntary Support of Education 1973-74, at $12(1975)$.

42. C.F.A.E. 1973-1974, at 12. 
Private gifts in $1973-74$ totalling $\$ 579,995,000$ had no restrictions or limitations placed on their use by recipients. Unrestricted support is particularly important to educational institutions and stands in sharp contrast to preconditions normally attendant upon federal assistance. For example, federal undergraduate institutional assistance, because of a variety of legal and political problems, is indexed to the number of students in attendance receiving some form of federal student aid, and then contingent upon 50 per cent funding of student entitlements. ${ }^{43}$ General federal assistance grants to graduate schools are conditioned upon agreement by the university not to reduce

TABLE VII

How Do They Give to Higher Education?

Outright Gifts as Compared to Life Income, Annuity and Bargain Sales For the 1962-63 Year

\begin{tabular}{|c|c|c|c|}
\hline \multirow[b]{2}{*}{ Type of Gift } & \multicolumn{3}{|c|}{ Under $\$ 5,000$} \\
\hline & $\begin{array}{c}\text { Donor } \\
\text { Transactions }\end{array}$ & Amount & $\%$ \\
\hline $\begin{array}{l}\text { Outright Gift } \\
\text { Life Income } \\
\text { Annuity Contracts } \\
\text { Bargain Sales }\end{array}$ & $\begin{array}{r}2,429,361 \\
1,429 \\
519 \\
124 \\
\end{array}$ & $\begin{array}{r}\$ 258,285,637 \\
910,741 \\
627,716 \\
130,701 \\
\end{array}$ & $\begin{array}{r}99.2 \\
.4 \\
.3 \\
.1\end{array}$ \\
\hline \multirow[t]{2}{*}{ TOTAL GIFTS } & $2,431,433$ & $\$ 259,954,795$ & 100.0 \\
\hline & & $\begin{array}{r}(25 \%) \\
\text { Over } \$ 5,000\end{array}$ & \\
\hline $\begin{array}{l}\text { Outright Gift } \\
\text { Life Income } \\
\text { Annuity Contracts } \\
\text { Bargain Sales }\end{array}$ & $\begin{array}{r}20,970 \\
473 \\
253 \\
57 \\
\end{array}$ & $\begin{array}{r}\$ 747,472,974 \\
18,942,416 \\
7,461,651 \\
1,004,441 \\
\end{array}$ & $\begin{array}{r}96.5 \\
2.4 \\
1.0 \\
.1 \\
\end{array}$ \\
\hline \multirow[t]{3}{*}{ TOTAL GIFTS } & 21,753 & $\$ 774,881,482$ & 100.0 \\
\hline & & $(75 \%)$ & \\
\hline & & Total & \\
\hline $\begin{array}{l}\text { Outright Gift } \\
\text { Life Income } \\
\text { Annuity Contracts } \\
\text { Bargain Sales }\end{array}$ & $\begin{array}{r}2,450,331 \\
1,902 \\
772 \\
181 \\
\end{array}$ & $\begin{array}{r}\$ 1,005,758,611 \\
19,853,157 \\
8,089,367 \\
1,135,142\end{array}$ & $\begin{array}{r}97.1 \\
2.0 \\
.8 \\
.1\end{array}$ \\
\hline TOTAL GIFTS & $2,453,186$ & $\$ 1,034,836,277$ & 100.0 \\
\hline
\end{tabular}

Source: J. Levi \& F. Vorsanger, Patterns of Giving to Higher Education: An Analysis of Contrubutions and Their Relations to Tax Policy 20 (1968).

43. See 20 U.S.C.A. $\$ 1070 \mathrm{e}(1974)$. 
the level of operating support from non-federal sources. ${ }^{44}$ Federal capitation grants to medical schools require the schools not only to increase enrollment even though the capitation grant may not cover increased costs, but also to develop new directions described as "curriculum improvements" emphasizing such matters as clinical pharmacology, drug and alcohol use and abuse, "significant" increase of "adequately trained" personnel, and the training "of primary health care professionals" particularly in family medicine. ${ }^{45}$ While each of the conditions prescribed in this federal legislation may be entirely praiseworthy, they reflect the judgment of others and substitute for the faculty which bears primary responsibility for the research and educational function.

The American Council on Education analyses covering the 1962-63 fiscal year achieved further refinement. In that year, 2,453,186 donor transactions brought gifts of $\$ 1,034$ billion. However, less than one per cent of all donor transactions accounted for 75 per cent of the total of all support. ${ }^{46}$ Table VII reflects these analyses.

Of this support 76.7 per cent was received in the form of cash, 17.7 per cent in the form of securities, and 5.6 per cent in the form of property, as shown in Table VIII. ${ }^{47}$

Table IX shows that the largest number of all donor transactions fell among the class of living alumni. Of a total in excess of 1,700,000 donor transactions, 91 per cent were for less than one hundred dollars, 99 per cent less than one thousand dollars. However, this 99 per cent produced only 34.3 per cent of total gifts received from living alumni. ${ }^{48}$

Table $X$ shows that the same pattern existed as to living non-alumni. ${ }^{49}$

As illustrated in Table XI, the importance of security gifts was indicated by the averaging of size of gift. ${ }^{50}$

Further detail was sought in the subsequent study 1970-71, illustrated in Table XII. Gift transactions were analyzed for all classes of institutions by class of donor, size of gift, and subject matter. ${ }^{51}$

\footnotetext{
44. See 20 U.S.C.A. $\S 1134 \mathrm{~s}(\mathrm{c})(2)$ (B) (1974).

45. See 42 U.S.C.A. § 295 (1974).

46. J. Levi \& F. Vorsanger, Patterns of Giving to Higher Education: An Analysis of Contributions and Their Relation to Tax Policy 20 (1968).

47. Id. at 31 .

48. Id. at 24 .

49. Id. at 31 .

Of 491,123 donor transactions 413,541 or $84 \%$ were under $\$ 100$ producing in the aggregate $\$ 12,488,571$ in gifts or $7.7 \%$ of all giving from each source. Donor transactions under $\$ 1,000$ totalled 476,611 or $97 \%$ of all donor transactions but in the aggregate produced $\$ 28,494,487$ in gifts representing only $17.6 \%$ of all gifts from this source. Conversely, 2,125 donor transactions each in excess of $\$ 10,000$ (or less than $1 \%$ of all donor transactions) produced more than $\$ 93,000,000$ or $58 \%$ of all gifts from this source.

50. Id. at 26.

51. J. Levi \& S. Steinbach, Patterns of Giving to Higher Education II: An Analysis of Voluntary Support of American Colleges and Universities 11 (1970-71).
} 


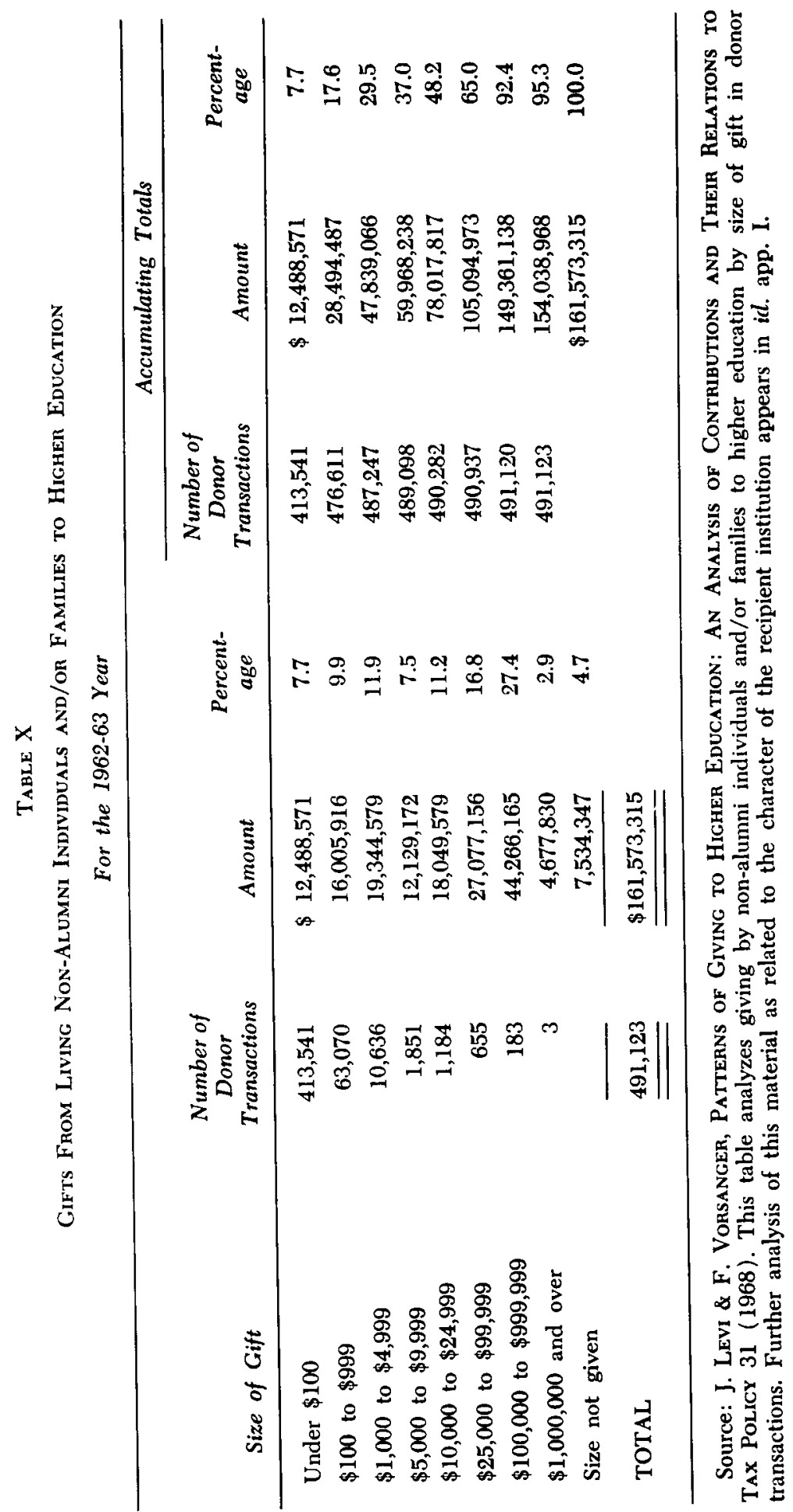


TABLE XI

Average Stze of GifT

By Type of Institution and Form of Gift Unweighted

\begin{tabular}{|c|c|c|c|c|}
\hline \multirow[b]{2}{*}{ Type of Institution } & \multicolumn{4}{|c|}{ Average Size of Transaction } \\
\hline & Cash & Securities & $\begin{array}{c}\text { Property } \\
\text { Other Than } \\
\text { Securities }\end{array}$ & $\begin{array}{c}\text { Com- } \\
\text { bined } \\
\text { Total }\end{array}$ \\
\hline Major Private Universities & $\$ 542$ & $\$ 16,111$ & $\$ 1,265$ & $\$ 727$ \\
\hline Public Institutions-State & 483 & 28,197 & 10,437 & 566 \\
\hline Private Men's Colleges & 305 & 14,881 & 906 & 437 \\
\hline Private Women's Colleges & 259 & 3,555 & 938 & 342 \\
\hline Private Co-ed Colleges & 290 & 8,259 & 563 & 358 \\
\hline Professional and Spec. Schools & 428 & 8,849 & 319 & 431 \\
\hline Municipal Colleges & 325 & 4,947 & 3,041 & 348 \\
\hline Junior Colleges & 176 & 17,949 & 38,872 & 452 \\
\hline $\begin{array}{l}\text { Average size of transaction } \\
\text { for all institutions }\end{array}$ & $\$ 439$ & $\$ 13,094$ & $\$ 1,101$ & $\$ 566$ \\
\hline
\end{tabular}

Source: J. Levi \& F. Vorsanger, Patterns of Giving to Higher Education: An Analysis of Conthibutions and Their Relations to Tax Policy 26 (1968).

Gifts of securities center in the individual classes of alumni and other individuals and families. 1970-71 was not a typical year. The C.F.A.E. reported that bequests had increased by 43.3 per cent from the previous year. ${ }^{52}$

As might be expected, there is a high degree of random variation in the amount of voluntary support from individuals received in the form of bequests. This factor was responsible for a large part of the upturn in total voluntary support in 1970-71, since reported bequests rose from $\$ 185.7$ million in $1969-70$ to $\$ 266.0$ million in $1970-71$, an increase of $43.3 \%$. This is the largest year-to-year movement in this figure since $1964-65$, and by a very wide margin. The dollar total of bequests amounted to $17.6 \%$ of the grand total of voluntary support; this compares with $12.6 \%$ in the previous year. In relation to the total support received from individuals, bequests accounted for well over one-third; this is the highest proportion on record during the last ten years. That the increase was widespread is shown by the fact that bequests as a percentage of support from all individuals rose for all classes of institutions except men's colleges, municipal colleges and universities, and junior colleges.

The Council for Financial Aid to Education 1972-73 report demonstrates the percentage of giving by bequest to be higher in the 1970-71 year than in all years from 1962 to 1973 inclusive. ${ }^{53}$

52. C.F.A.E. $1970-71$, at 68 .

53. C.F.A.E. 1972-73, at 12 . 


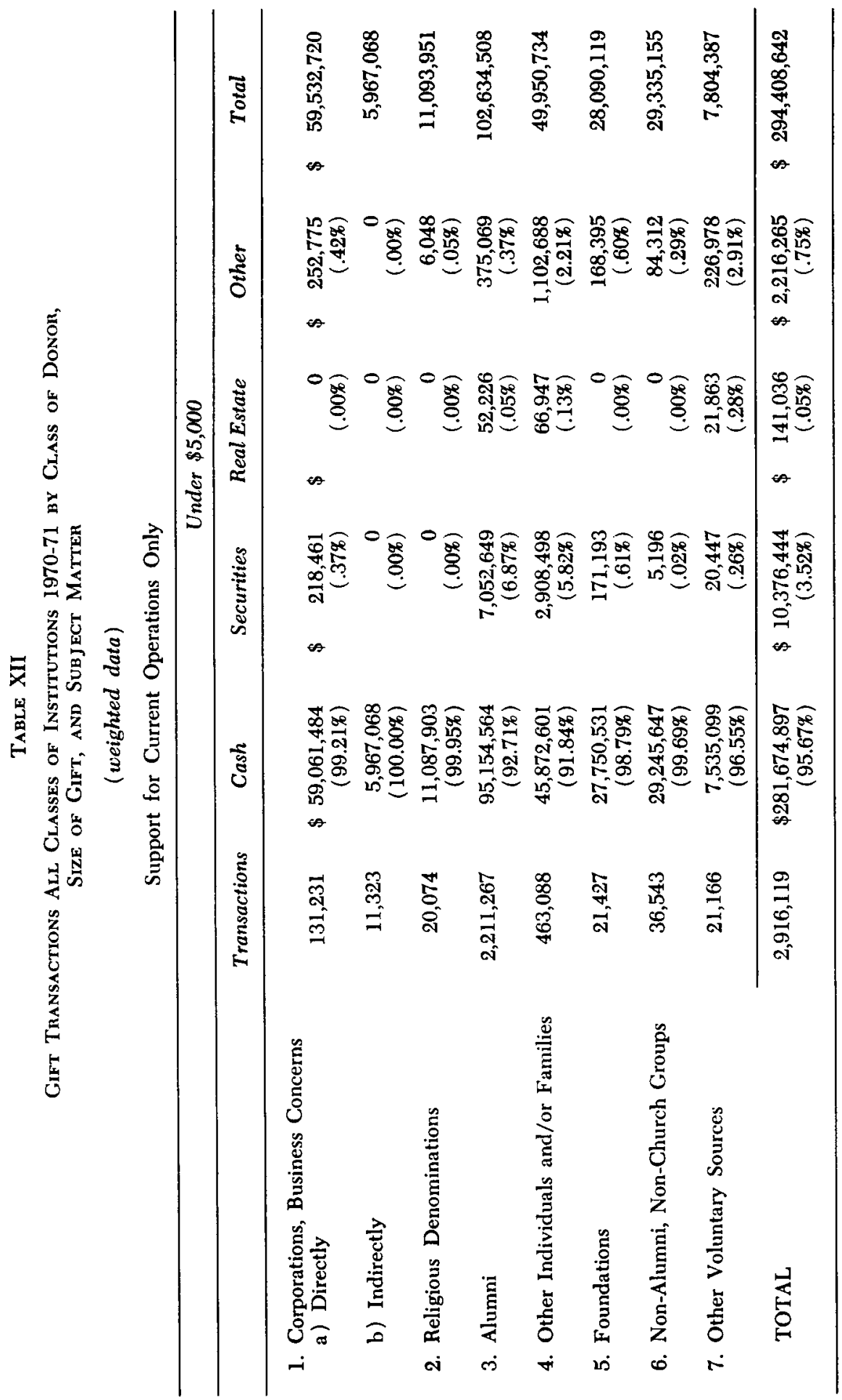




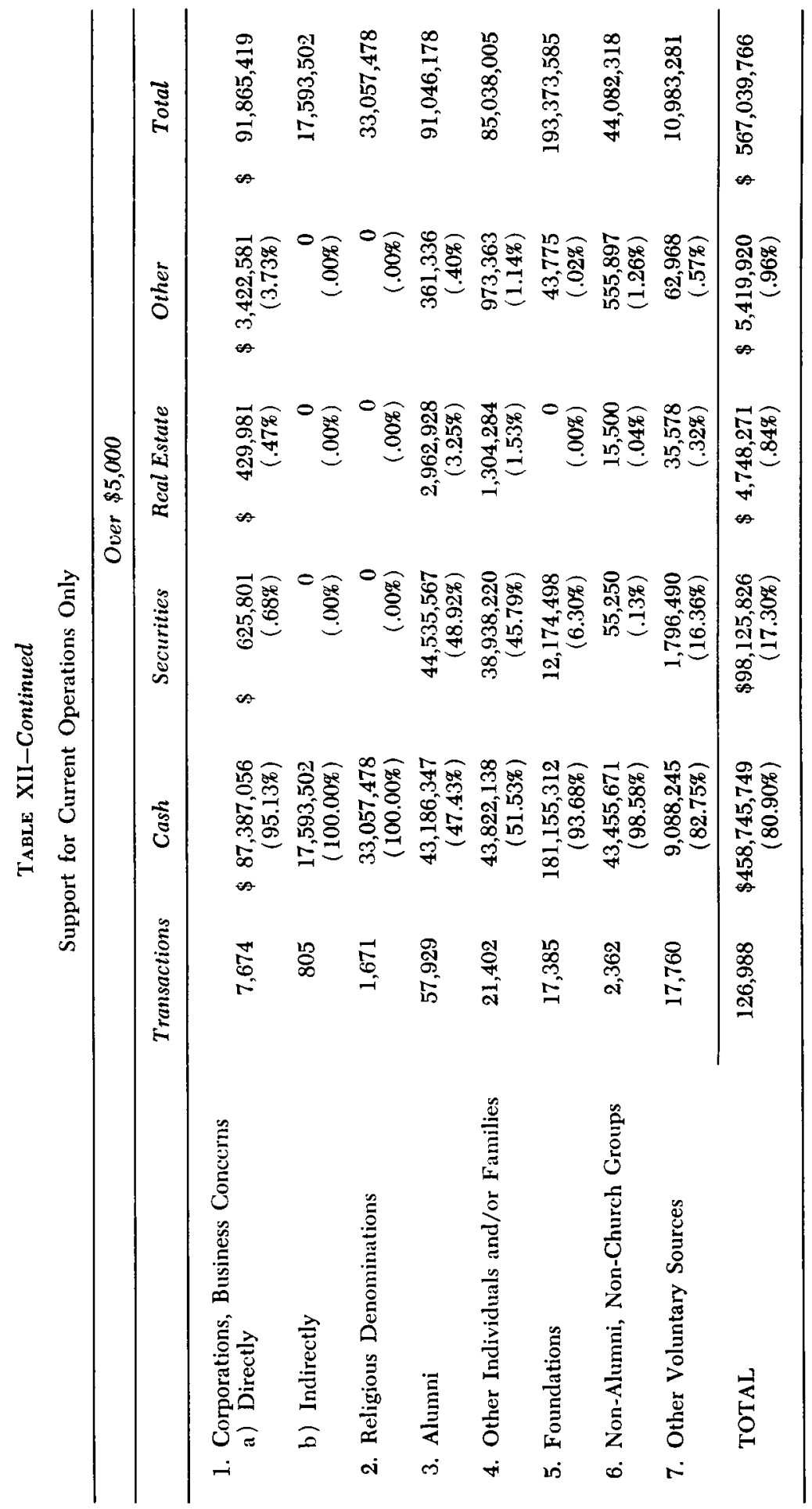




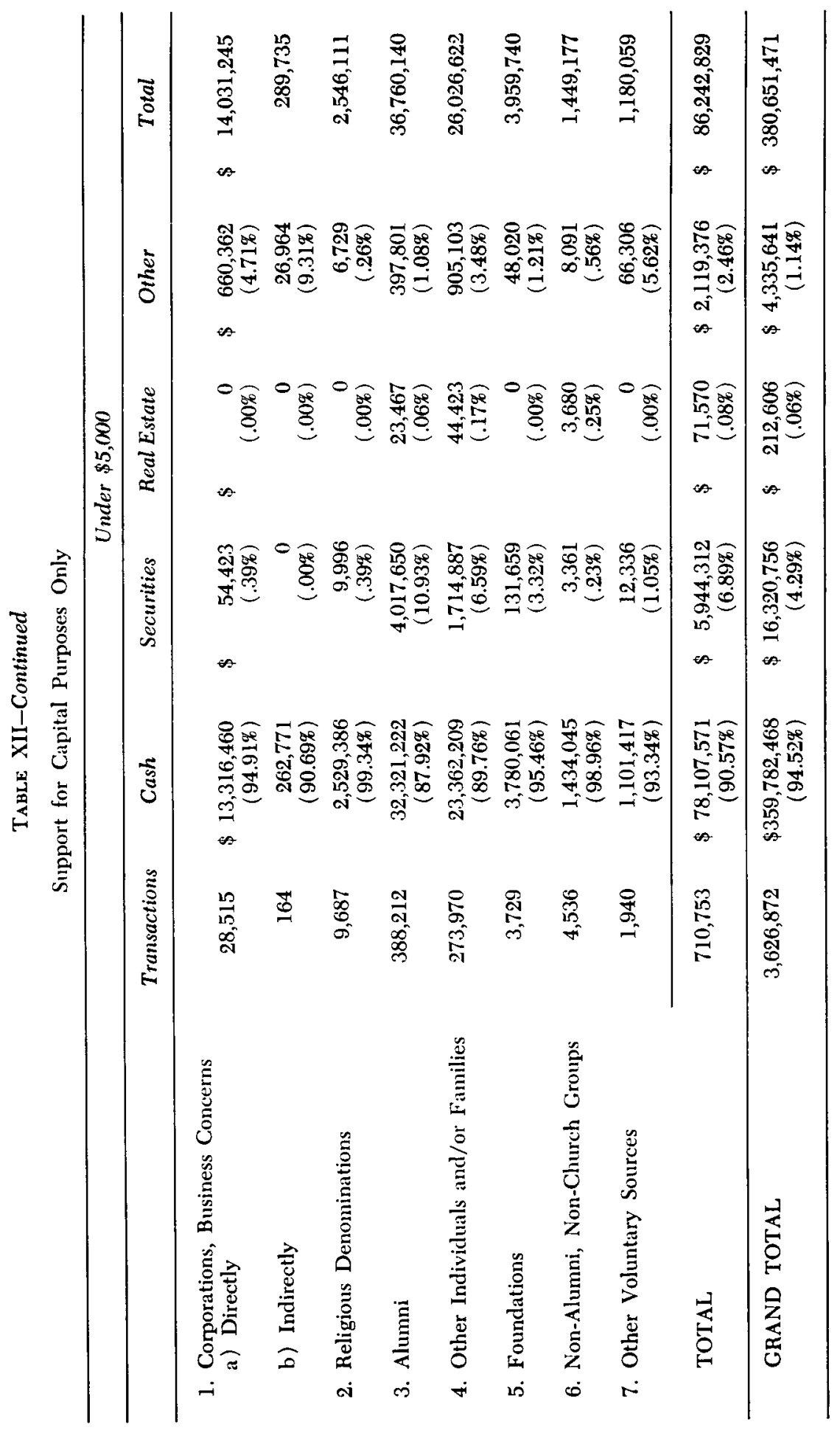


TABLE XIII

Forms of Individual Grving as a Percentage of Voluntary Support BY INDIVIDUALS 1973-74

\begin{tabular}{cccccc}
\hline Year & $\begin{array}{c}\text { Bequests } \\
\text { (per cent) }\end{array}$ & $\begin{array}{c}\text { Deferred } \\
\text { Giving } \\
\text { (per cent) }\end{array}$ & Year & $\begin{array}{c}\text { Bequests } \\
\text { (per cent) }\end{array}$ & $\begin{array}{c}\text { Deferred } \\
\text { Giving } \\
\text { (per cent) }\end{array}$ \\
\hline $1962-63$ & 34.4 & 3.5 & $1968-69$ & 26.6 & 5.4 \\
$1964-65$ & 31.4 & 6.7 & $1969-70$ & 27.3 & 5.0 \\
$1965-66$ & 30.1 & 6.8 & $1970-71$ & 34.9 & 3.9 \\
$1966-67$ & 25.5 & 6.1 & $1971-72$ & 32.0 & 6.4 \\
$1967-68$ & 25.1 & 7.1 & $1972-73$ & 28.8 & 9.0 \\
\hline
\end{tabular}

Source: Councll for Financial Am to Education, Voluntary Support of Education $1972-73$, at $12(1974)$.

Subject to this caution it is possible to reconstruct gifts of property as compared to cash for $1970-71$ as between bequests and gifts from living individuals. ${ }^{54}$

\section{TABLE XIV}

Voluntapy Support gy Individuals

$(\$ \text { millions })^{1}$

Gifts over $\$ 5,000,1970-71$

\begin{tabular}{ccccc}
\hline & Cash & Property & Total & $\begin{array}{c}\text { All Gifts } \\
\text { Total }\end{array}$ \\
\hline Lifetime gifts & $\$ 75$ & $\$ 69$ & $\$ 144$ & $\$ 249$ \\
Bequests & 68 & 149 & 215 & 219 \\
TOTAL & $\$ 143$ & $\$ 215$ & $\$ 359$ & $\$ 468$ \\
\hline
\end{tabular}

${ }^{1}$ Unweighted data adjusted; adjusted data may not add precisely because of rounding.

Source: Letter From Julian H. Levi and Sheldon Steinbach, American Council on Education to Gabriel G. Rudney, Commission on Private Philanthropy, Nov. 8, 1974.

These conclusions are established in the American Council on Education Survey Patterns of Giving to Higher Education III. This study, limited solely to support procided by alumni and non-alumni individuals, again

1. demonstrated the importance of the large gift; $;^{55}$

54. Letter from Julian H. Levi and Sheldon Steinbach, American Council on Education to Gabriel G. Rudney, Commission on Private Philanthropy, Nov. 8, 1974.

55. J. Levi \& S. Steinbach, Patterns of Giving to Higher Education III: An Analysis of Voluntary Support of American Colleges and Universities 13 (1973-74). 
[Vol. 39: No. 4

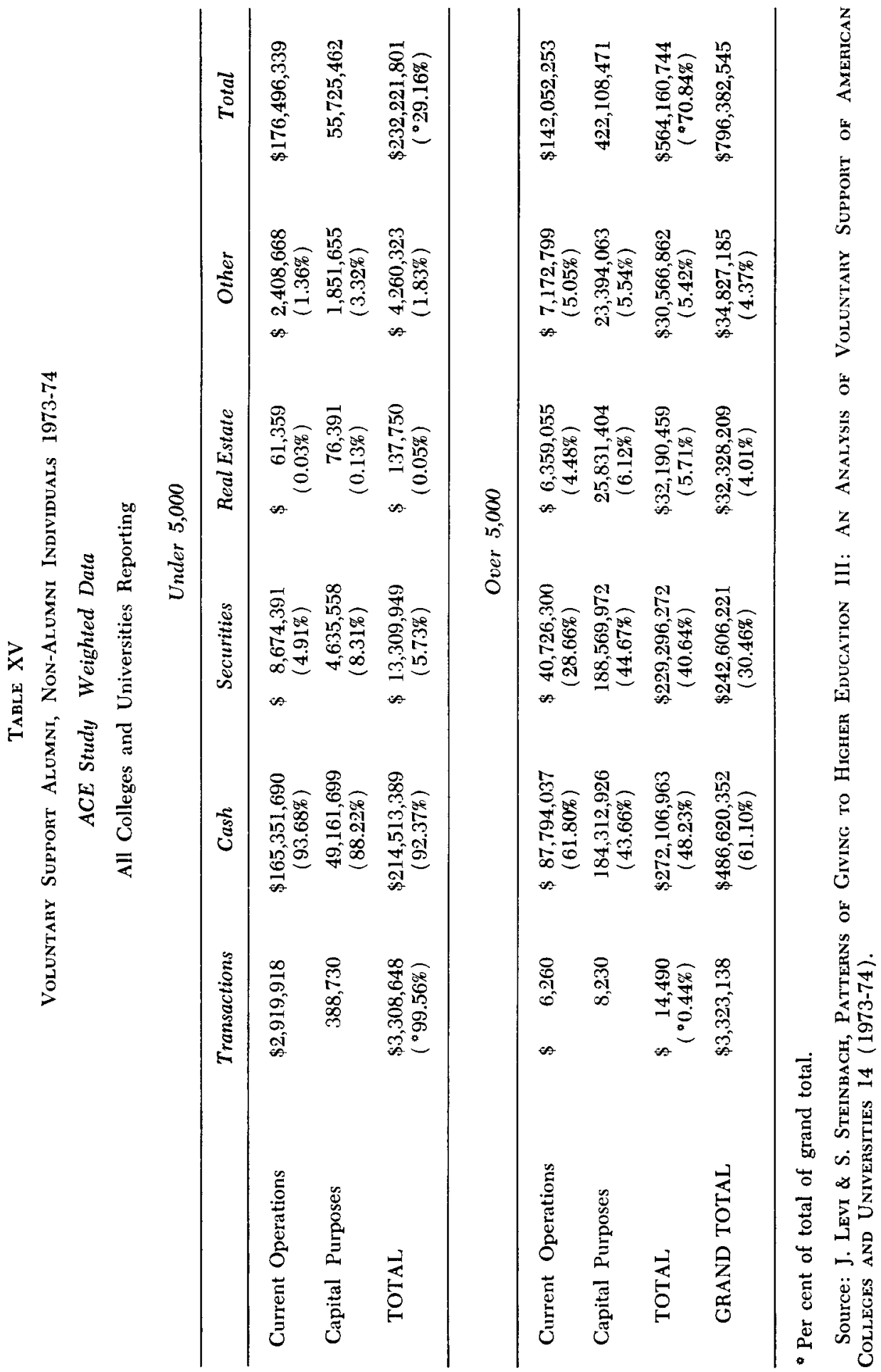




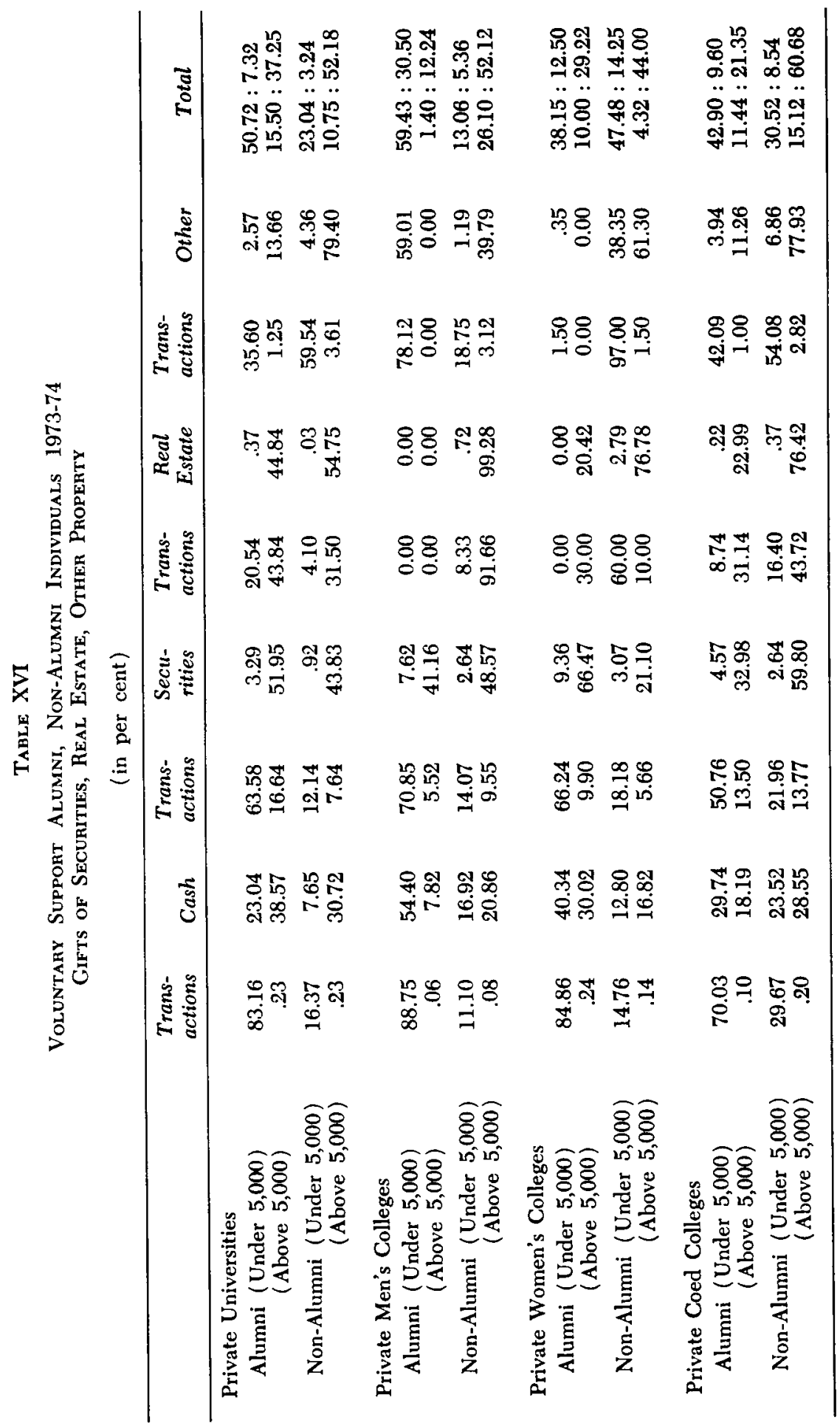




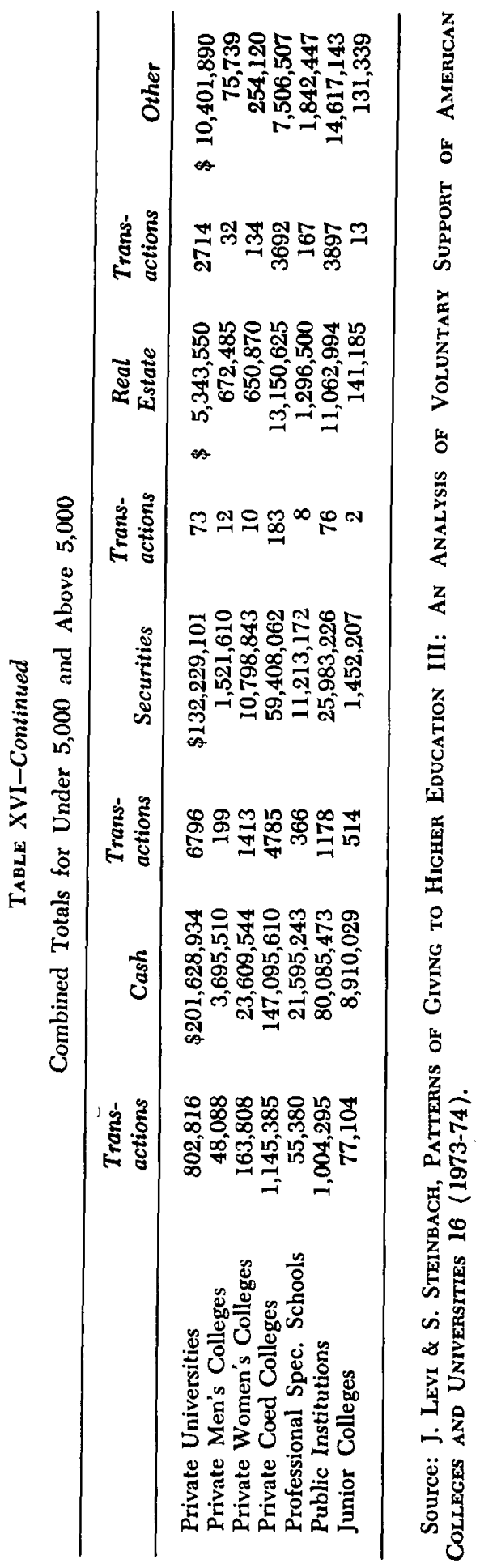




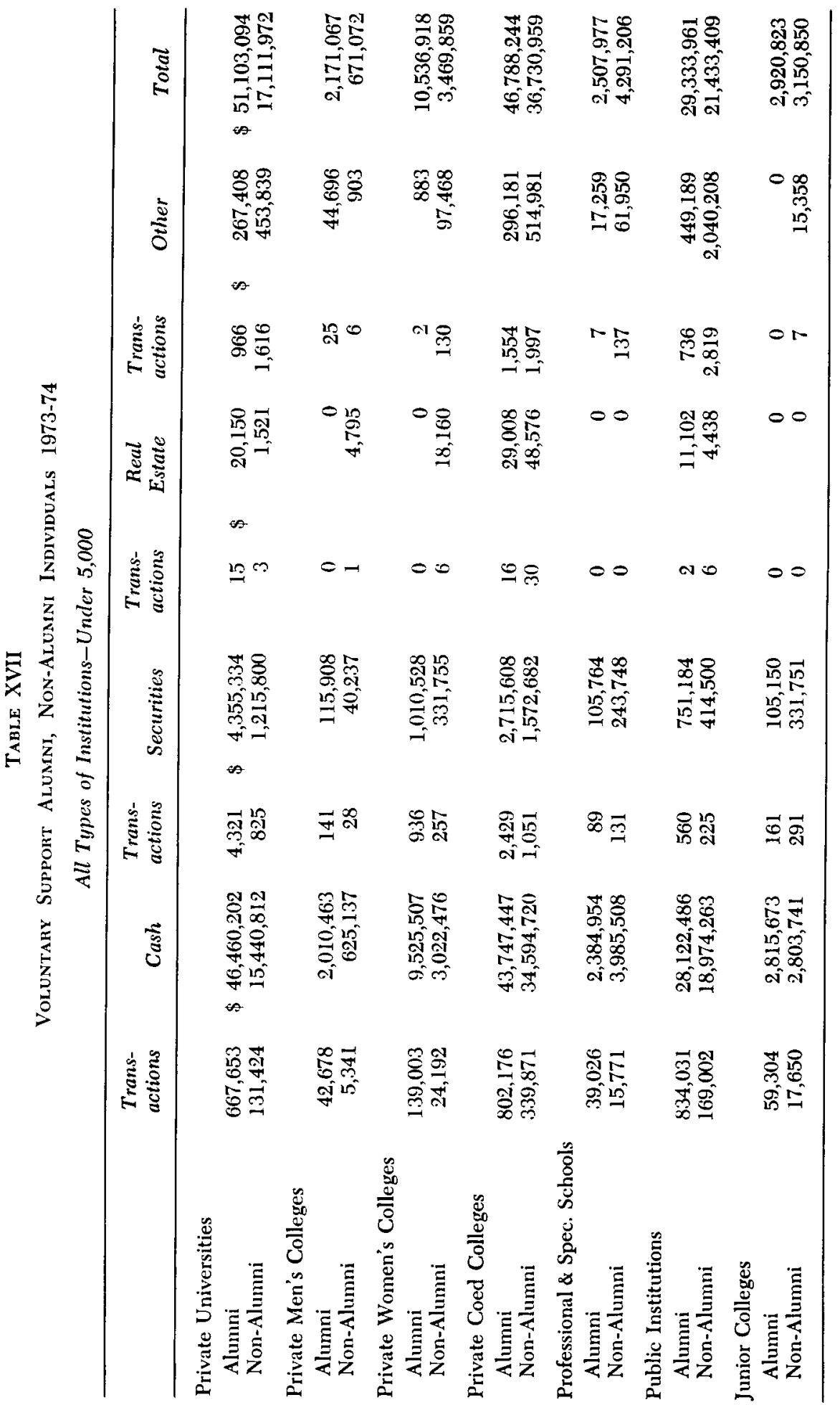


Page 75: Autumn 1975]

Education

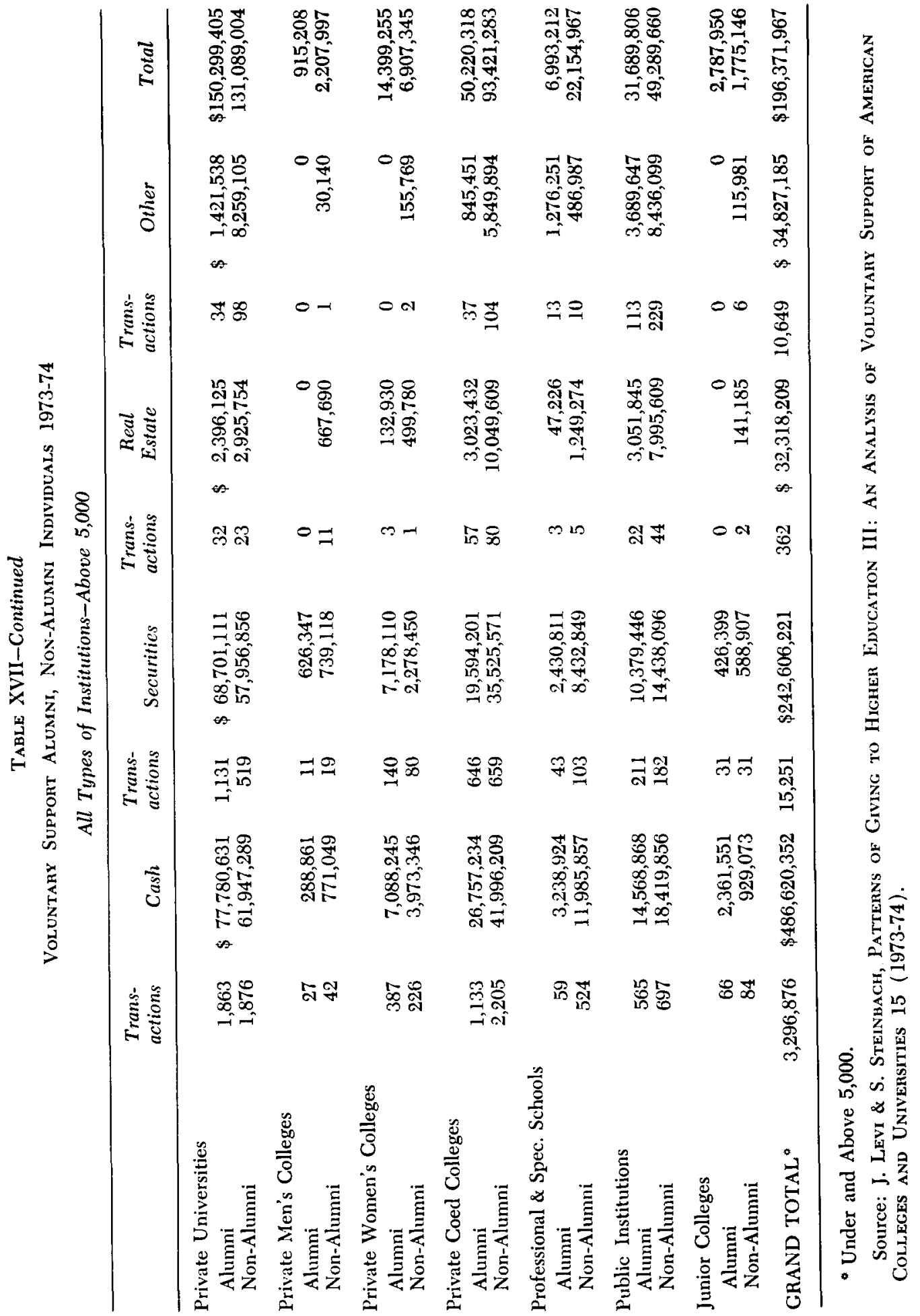


2. demonstrated the importance of gifts of securities, real estate, and other property; ${ }^{56}$ and

3. demonstrated the importance of such support to all types of institutions. ${ }^{57}$

It is also possible to reconstruct gifts of property as compared to cash for 1973-74 as between bequests and gifts from living individuals. ${ }^{58}$

TABLE XVIII

LifeTime GifTs vs. Bequests

(dollars/per cent)

\begin{tabular}{lrrrr}
\hline & \multicolumn{1}{c}{ Cash } & Securities & Real Estate & \multicolumn{1}{c}{ Cash } \\
\hline Bequests & $110,315,530$ & $74,310,645$ & $5,142,413$ & 762,761 \\
\multirow{2}{*}{ Inter Vivos Gifts } & $61.7 \%$ & $46.9 \%$ & $24.7 \%$ & $3.7 \%$ \\
& $68,507,364$ & $84,034,579$ & $15,668,248$ & $19,686,959$ \\
Total Giving & $38.3 \%$ & $53.1 \%$ & $75.3 \%$ & $96.3 \%$ \\
& $178,822,894$ & $158,345,224$ & $20,810,661$ & $20,449,720$ \\
& $100.0 \%$ & $100.0 \%$ & $100.0 \%$ & $100.0 \%$ \\
\hline
\end{tabular}

Source: J. Levi \& S. Steinbach, Patterns of Giving to Higher Education III: AN Analysis of Voluntary Support of American Colleges and Universities 20 (1973-74).

The importance of individual gifts of securities is also reflected in statistics gathered by the Pennsylvania Association of Colleges and Universities. Its report stated that for the year 1969 through $1972:{ }^{59}$

(1) Of total annual gift receipts, an average of $54.5 \%$ was attributable to gifts from individuals;

(2) Of total annual gifts from individuals, an average of $40.0 \%$ constituted gifts of securities and real estate; and

(3) Of total annual gifts from individuals, an average of $31.4 \%$ were bequests. ....

While averages are illustrative, to individual institutions such figures are critical. For example, for Lafayette $74.7 \%$ of all gifts were from individuals, for Carnegie-Mellon $79.8 \%$ of gifts from individuals consisted of gifts of securities and real estate, and for Lycoming $64.9 \%$ of gifts from individuals were bequests.

It is evident from these studies that colleges and universities, with the help of whatever incentive the tax laws provide, have developed regular and dependable sources of voluntary support of sufficient magnitude to play an important role in achieving their educational mission. Any change in the tax law

56. Id. at 16

57. Id. at 15 .

58. Id. at 20 .

59. See 119 Cong. Rec. 11,637-638 (1973). 
that would reduce the incentive for charitable donations would obviously impair our system of higher education which is justifiably envied throughout the world for its diversity and variety. Of course, critics of the existing tax laws are careful to suggest that reductions in voluntary support should be matched by federal assistance. Further, it has been claimed that the charitable contribution deduction is inefficient, costing the government more in lost tax revenue than the reductions in contributions which would occur if such deductions were eliminated, or, at least, limited. ${ }^{60}$ However, more recent studies suggest to the contrary, that the deduction as presently constituted is an efficient incentive for voluntary support, and that critics who wish to substitute federal assistance for voluntary support seem to ignore the substantial, nonquantifiable costs which this would occasion for our educational system.

The Commission on Private Philanthropy and Public Needs commissioned studies by Professor Milton S. Feldstein and the University of Michigan Survey Research Center.

1. Charitable contributions are increased substantially by current provision of deductibility: ${ }^{61}$

The results ... indicate that charitable contributions are increased substantially by the current provision of deductibility. The alternative estimates of the price elasticity are generally greater than one and cluster around 1.1. This implies that the "efficiency" of the deduction as a stimulant to giving exceeds 100 percent: the deduction increases the amount received by charities by somewhat more than it reduces the revenue collected by the Treasury.

2. Charitable giving to educational institutions and hospitals are very sensitive to potential tax changes: ${ }^{62}$

The sensitivity of charitable giving to potential tax changes differs substantially among the major types of donees. Gifts to educational institutions and hospials are very sensitive to the cost of giving while religious organizations are much less sensitive than the others. Eliminating the charitable deduction would reduce total individual giving by an estimated 20 percent, but religious gifts would fall by only some 14 percent while gifts to educational institutions and hospitals would be cut approximately in half. Although replacing the current deductible by a 30 percent tax credit would increase total giving by some 15 percent, educational institutions and hospitals would still lose about 20 percent of current gifts.

Among the contingencies analyzed by Professor Feldstein is restriction of deductibility of gifts of appreciated property to the tax base of the donor (this, of course, was the substance of the proposal advocated to the Ways and

60. McDaniel, An Alternative to the Federal Income Tax Deduction in Support of Private Philanthropy, supra note 5 , at 171 .

61. Feldstein, Taxes and Charitable Contributions: Part I-The Aggregate and Distributional Effects, 28 NAT'L TAX J. 81,82 (1975).

62. Feldstein, Taxes and Charitable Contributions: Part II-The Impact on Religious, Educational, and Other Organizations, 28 NAT'L TAX J. 209, 224 (1975). 
Means Committee on August 2, 1974). ${ }^{63}$ Professor Feldstein found that the effect of this change in the law would (a) decrease gifts by $\$ .643$ billion, and (b) increase income taxes by $\$ .484$ billion. Thus, for every dollar of increased tax revenue a decrease of $\$ 1.329$ in charitable support would occur. The heaviest burden of these losses in support would fall upon education, hospitals, and health and welfare agencies. Interestingly enough, personal disposable income of the wealthy would be increased substantially. ${ }^{64}$

The Filer Commission found: ${ }^{65}$

Based on estimates prepared by the Treasury, approximately 50 per cent of reported property gifts are made by persons having annual incomes of $\$ 100,000$ or more. Polling for the Commission by the University of Michigan's Survey Research Center found that only a small percentage of people in the lower-income categories made non-money gif ts to charity, but the percentage rises at the highest incomes, reaching 47 per cent for those with incomes of $\$ 500,000$ or more and accounting for 80 per cent of all charitable giving by this group.

Thus, the Filer Commission concluded:

First, many institutions rely heavily for support on appreciated property gifts, primarily private colleges, universities, hospitals and cultural organizations that tend to be the principal recipients of contributions by upper-income givers. This is not only because proportionately more high-income givers give non-cash gifts than do lower-income donors. It is also because at upper-income levels those who give appreciated property give far more generously than those who contribute only cash. Treasury statistics show that the average gift by non-cash givers with incomes of $\$ 500,000$ or more is four times the size of the average gift of those at the same income level who give only in cash. Thus, according to computerized simulations, overall giving would drop by 3 per cent if the appreciated property allowance were eliminated, and the greatest proportion of the loss would be borne by educational organizations, which could expect an 8 per cent decrease in private funds they receive, or around $\$ 50$ million less a year, based on 1970 dollar values. Many institutions assert that support induced by the appreciated property allowance is critical to the sustaining of their customary standards, some to their very existence.

When the Feldstein analysis is applied to the figures contained in the tax expenditure budget submitted to Congress in January $1975,{ }^{66}$ it can be seen that elimination of the charitable contribution deduction for gifts to higher education for fiscal years 1975 and 1976 would increase tax revenues from individuals by $\$ 405$ and $\$ 435$ million, respectively; and would reduce voluntary support for higher education by sums in excess of $\$ 545$ and $\$ 565$ million, re-

63. Committee on Ways and Means, supra note 27.

64. M. Feldstein, On the Effects of the Income Tax Treatment of Charitable Contributions: Some Preliminary Results 39, December 20, 1973 (unpublished manuscript on file with author), reviewed, An Incentiz'e That Works, 7 Philanthropy Monthly 6, 8 (December 1974).

65. Commin on Private Philanthropy and Public Nefds, Giving in America: Toward a Stronger Voluntary Sector 144.45, 143, 146, 208-09 (1975).

66. Special Analyses, supra note 2. 
spectively. This is exclusive of that portion of charitable contributions which, although classified for health and welfare, also support higher education. If certain of the changes advocated were to occur, contribution losses to higher education would be even greater. In some instances the loss can be calculated on a ratio of $\$ 1.86$ of decrease in charitable contributions per one dollar of "tax expenditure."

This would be a devastating loss of voluntary support to higher education and would have to be replaced by some form of additional direct expenditure by the federal government. ${ }^{67}$ Uncertainties in tax consequences of deferred giving in 1969 reduced this form of support by one-half or more than fifty million dollars. ${ }^{68}$

Those who would substitute federal support for the private charitable gift $^{69}$ might first examine the reliability of federal support of higher education. The first step for any government program is the enactment of "authorization" legislation by the Congress together with approval by the President. Appropriation legislation is thereafter enacted by the Congress and approved by the President for each annual fiscal year except for the rare and dubious practice of United States Treasury guarantee of agency obligations-so-called "back-door" financing. Even thereafter, however, support is reduced by impoundments and rescissions. Actual appropriations may fall far short of authorizations. $^{70}$

The formidable extent of federal short-fall is shown in the following statistics in Table XIX. ${ }^{71}$

Fiscal Year 1976 Budget Proposals demonstrate the continuing erosion, as shown in Table XX.72

The short-falls as well as the recissions create substantial hardships for colleges and universities and their students. Consider, for example, the Land Grant College Program (the Morrill Act) which has been a part of Federal Statutes since July 2, $1862 .{ }^{73}$ Annual appropriations were authorized on August 30, 1890 to be paid on or before the thirty-first day of July of each year. ${ }^{74}$ Additional appropriations were authorized in 1935, increased in 1952 and again in 1960 and $1966 .^{75}$ Now the 1976 Budget proposes complete elimination of annual and permanent payments to Land Grant Colleges.

67. Chronicle of Higher Ed., Sept. 22, 1975, at 3.

68. J. Levi \& S. STEInbach, supra note 51 , at 25.

69. See, e.g., McDaniel, Federal Matching Grants for Charitable Contribution: A Substitute for the Income Tax Deduction, supra note 5.

70. S. SURREY, supra note 3 , at 232.

71. These figures were provided through the offices of Charles W. Lee, Executive Director, Committee for Full Funding of Educational Programs, Washington, D.C.

72. See letter from Charles W. Lee to Julian H. Levi, Feb. 13, 1975.

73. 7 U.S.C.A. $\$ 301$ et seq. (1964).

74. Id. $\S 322$.

75. Id. $\$ 324$. 


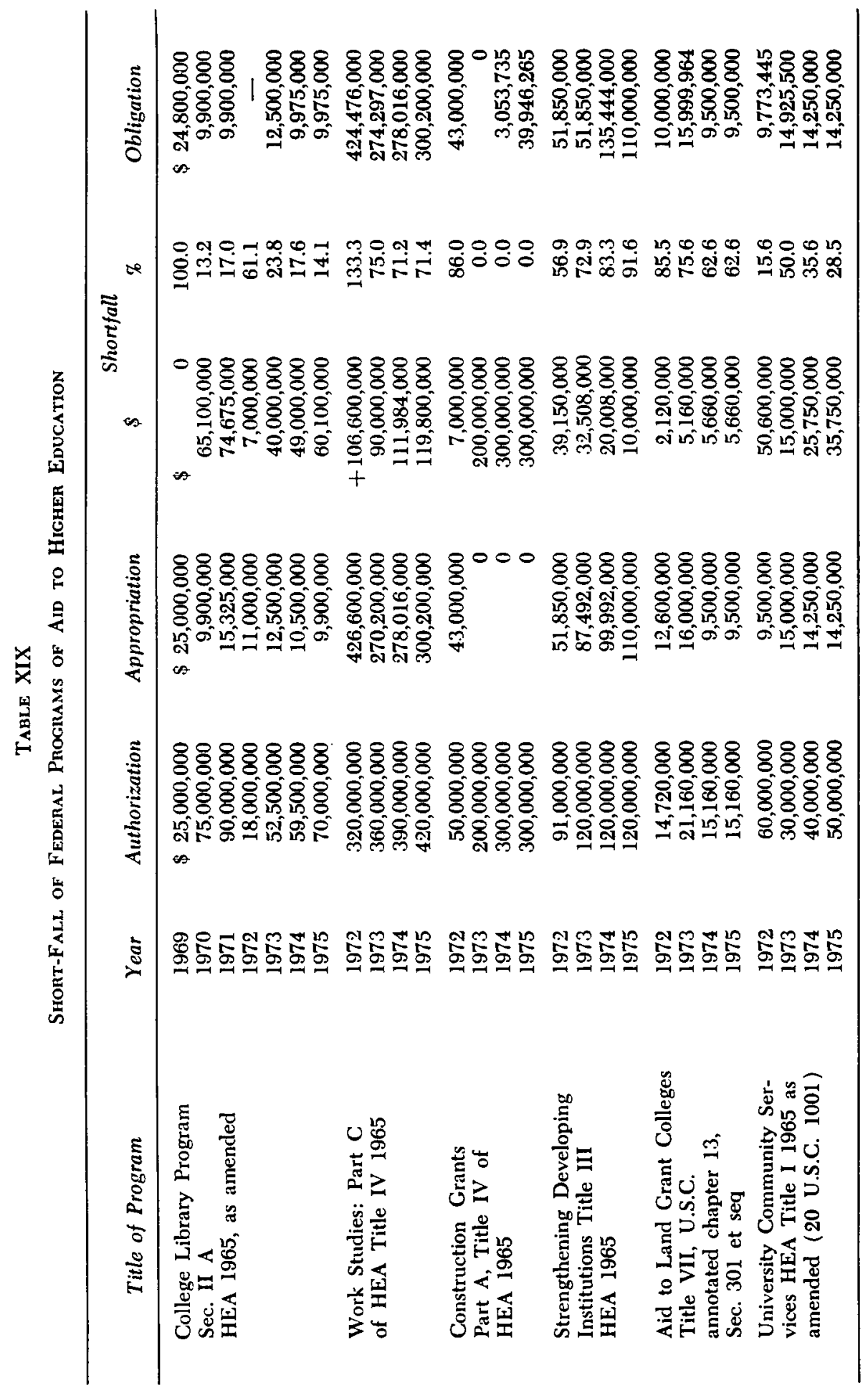




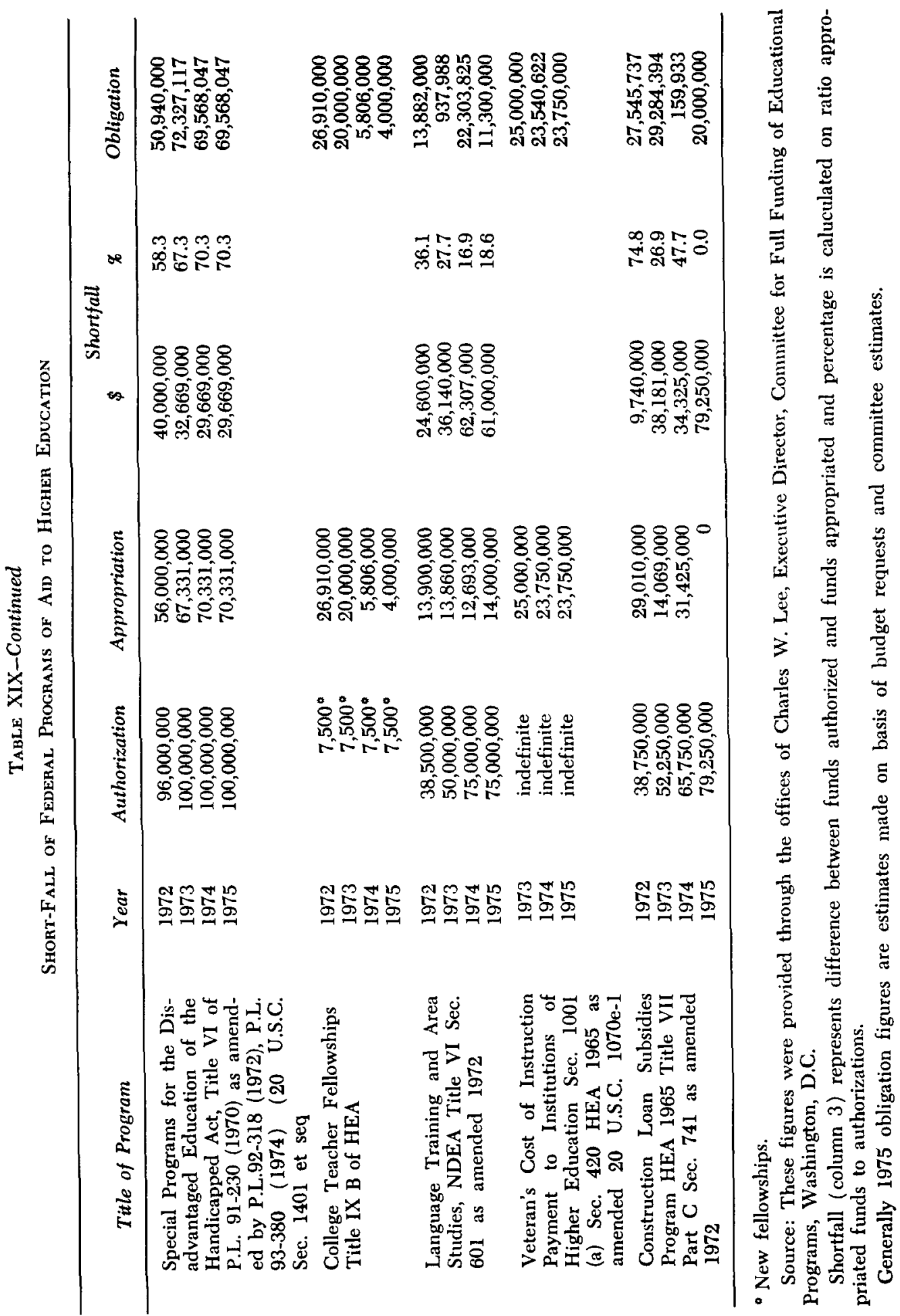


TABLE XX

Health Education Program Decreases Sought in FY 1976 Proposals (without recission adjustment) (in thousands)

\begin{tabular}{|c|c|c|c|}
\hline Program & $\begin{array}{l}1975 \\
\text { App. }\end{array}$ & $\begin{array}{c}1976 \\
\text { Budget }\end{array}$ & Decrease \\
\hline \multicolumn{4}{|l|}{ Student Assistance: } \\
\hline SEOG's & $\$ 240,300$ & $-0-$ & $\$ 240,300$ \\
\hline Work-Study & 300,200 & $\$ 250,000$ & 50,200 \\
\hline \multicolumn{4}{|l|}{ NDEA II Loans: } \\
\hline Capital Contributions & 321,000 & $-0-$ & 321,000 \\
\hline Loans, Institutional & 2,000 & $-0-$ & 2,000 \\
\hline \multicolumn{4}{|l|}{ Institutional Assistance: } \\
\hline \multicolumn{4}{|l|}{ Lang. Tng. and Area Studies } \\
\hline Centers, Research, Fellows & 11,300 & 8,640 & 2,660 \\
\hline Fullbright Fellowships & 2,700 & 1,360 & 1,340 \\
\hline HEA I Univ. Comm. Sves. & 14,250 & $-0-$ & 14,250 \\
\hline \multicolumn{4}{|l|}{ Land-Grant Colleges: } \\
\hline Annual & 9,500 & $-0-$ & 9,500 \\
\hline Permanent & 2,700 & $-0-$ & 2,700 \\
\hline \multicolumn{4}{|l|}{ State P/S Comms.: } \\
\hline State Administration & 1,000 & $-0-$ & 1,000 \\
\hline Comprehensive Planning & 2,000 & -0 & 2,000 \\
\hline Veterans Cost of Inst. & 23,750 & -0 & 23,750 \\
\hline Cooperative Ed. & 10,750 & 8,000 & 2,750 \\
\hline \multicolumn{4}{|l|}{ Personnel Development: } \\
\hline College Teacher Fellows & 4,000 & 1,000 & 3,000 \\
\hline Pub. Svc. Fellows & 4,000 & -0 & 4,000 \\
\hline Mining Fellows & 1,500 & $-0-$ & 1,500 \\
\hline \multirow[t]{2}{*}{ Ethnic Heritage Studies } & 1,800 & $-0-$ & 1,800 \\
\hline & & Decrease & $\$ 683,750$ \\
\hline
\end{tabular}

Decreases in Other Budget Account Headings Affecting Higher Education Funding

\begin{tabular}{cccc}
\hline Program & $\begin{array}{c}1975 \\
\text { App. }\end{array}$ & $\begin{array}{c}1976 \\
\text { Budget }\end{array}$ & Decrease \\
\hline $\begin{array}{c}\text { Occupational, Vocational and Adult: } \\
\text { Education Personnel (EPDA) }\end{array}$ & & & \\
$\quad \begin{array}{c}\text { Pt. E Higher Education } \\
\text { Library Services: }\end{array}$ & $\$ 2,100$ & $-0-$ & $\$ 2,100$ \\
HEA II College Libraries & 9,975 & $-0-$ & 9,975 \\
HEA VI Undergrad. Inst. & 7,500 & $-0-$ & $\frac{7,500}{}$ \\
& & Decrease & $\$ 19,575$ \\
& TOTAL DECREASES & $\$ 703,325$ \\
\hline
\end{tabular}

Source: Letter from Charles W. Lee, Executive Director, Committee for Full Funding of Educational Programs, Washington, D.C. to Julian H. Levi, Feb. 13, 1973. 
Students admitted under scholarship or fellowship aid in various programs had every right to assume that this assistance would continue. They now find support suspended or eliminated. Universities and colleges, in good faith, added personnel, inaugurated programs to serve veterans, undertook language training and area studies, made commitments with local communities, took on students as trainees in programs for the handicapped, only to now find the federal commitment collapsible.

In contrast, private donors rarely say to their charities that they have "authorized a gift" and subsequently that they have "appropriated a lesser amount," and when the time of disbursement comes, advise that a portion of the support has been "rescinded or impounded." Even if some were to do so, they would never control a significant portion of the institution's support.

Since 1935 the American Association of Fund Raising Counsel has followed the activities of professional fund-raising counseling firms who serve annually more than one thousand hospitals, colleges and universities, church organizations, welfare and health agencies, and cultural institutions. These firms help to plan and implement private fund-raising and development programs. ${ }^{76}$ They report the extent to which private donors honor their pledges. The United Way of America averages 95 per cent in gift fulfillments. United Cerebral Palsy, from an annual telethon, receives more than 95 per cent of each dollar promised. The Muscular Dystrophy Association announced on February 19, 1975, that "collections on pledges made on the Jerry Lewis Labor Day Telethon have topped the 100 per cent mark." 77 Higher education pledge fulfillment averages around 98 per cent. In hospital campaigns the figure is estimated at 97 per cent. The National Council of Churches states that 95 per cent of the church-givers fulfill their pledges. This realization is all the more impressive in that in most instances the private pledge to contribute is not considered as creating a legal obligation and, as a matter of practice, donees do not resort to a legal remedy. The federal commitment simply is not as good as the sense of honor of the private donor.

The possibility of decreased private support comes at the worst of times. ${ }^{78}$ The Chronicle of Higher Education of August 5, 1974 published a list of seventytwo private colleges, principally liberal arts schools, obliged to close, merge, or be absorbed by public institutions since January $1,1970{ }^{79}$ The annual report of the United States Education Commissioner noted that seventeen private

76. See letter from John J. Schwartz, American Association of Fund Raising Counsel, Inc. to Julian H. Levi, Feb. 14, 1975.

77. See Chicago Sun Times, Feb. 19, 1975, at 32, col. 2.

78. Departiment of Health, Education, and Welfare, Financial Statistics of Institutions of Higher Education: Current Funds, Revenues and Expenditures 1971-72, at 5 (1974).

79. Chronicle of Higher Ed., Aug. 5, 1974, at 5. 
colleges had closed their doors in the 1972-73 academic year. The New York Times reported: ${ }^{80}$

The institutional beggars of American society-thousands of nonprofit organizations, including schools, libraries, hospitals and foundations-are studying the daily stock market tables with a growing sense of horror. Last week's rally must have pleased them. But for investments that have lost half their value, a rise of 10 to 15 percent wasn't enough to allay the gloom.

Because they live for the most part on the endowments left them by wealthy benefactors, these institutions have been trapped in a financial corner as the nation's stock and bond markets have plummeted. None of them make money on their operations, and so they are dependent on the dividends and interest paid on securities to meet their deficits.

To compound the problem of shrinking portfolios have come soaring expenses. Dartmouth College is in Hanover, New Hampshire, blanketed in snow during the winter. The result: A fuel bill that this year is expected to be $\$ 900,000$ more than the $\$ 450,000$ that was budgeted for last year.

Science Magazine, stated: $:^{81}$

Harvard University and Massachusetts Institute of Technology are contemplating staff deductions next year as a means of trimming rapidly rising budget deficits. Both schools have dwindling special funds to cushion them, and the staff cuts being proposed are likely to be relatively small. But that such measures are being taken by these traditionally wealthy institutions is a grim indication of the problems facing science and engineering schools which are less well-off.

....

Spokesmen at both schools say that inflation and rising energy costs, combined with the shrinking income from endowments and the inherent limits on raising tuition, mean that chronic gaps are developing between expenses and incomes.

There is a great deal at stake in maintaining a degree of independence or even insulation from federal or government control. ${ }^{82}$ The essential char-. acteristic of private support is that rejection by any one donor does not terminate the issue. Any college or university can and will continue to make its case and seek support from the multiplicity of other private sources. In contrast, if the National Institutes of Health or the National Science Foundation, or the Appropriations Committee of the Congress holding jurisdiction reject a proposal, few, if any public support alternatives are available.

Moreover, no government program of support can or ought to be expected to achieve the freedom of action available to the private donor. Public and private donors of necessity view their accountability quite differently. Public constraints applicable to a private donor whether individual, foundation, or corporation, are essentially negative. The special deductible feature of gifts

80. N.Y. Times, Oct. $13,1974, \S 4$, at 9 , col. 1 .

81. Shapley, Hariard, MIT Face Limits to Growth, 187 SCIENCE 939 (1975).

82. Compare S. SurReY, supra note 3, at 232. 
to public charities arises only when that charity has made application to the Internal Revenue Service and, after investigation, secured appropriate certification. ${ }^{83}$ Thus, the class of eligible donees is circumscribed by public policy determined by the Congress and administered by the Internal Revenue Service. Beyond that, however, the decision of the private donor to make a gift-the choice and positive act-is a matter of the donor's own conscience and judgment.

Public officials administering government funds have far greater public constraints. These officials must account to legislators who inevitably react to the common denominator of their constituency; the administrator of public funds will understandably tend to proceed along these accepted and established lines most easily justifiable to common belief.

From time to time legislators amuse themselves and their constituents by announcing the titles of various research investigations considered as examples of the absurdities of the academic mind. "Sen. William Proxmire (D-Wis.) said Tuesday the National Science Foundation is squandering $\$ 84,000$ to study why people fall in love. He said it was his choice 'for the biggest waste of the taxpayer's money for the month of March.' "The Senator's other choices are: " $\$ 15,000$ to study hitchhiking. $\$ 81,000$ to study the social behavior of the Alaskan brown bear. $\$ 25,000$ to study primate teeth. $\$ 112,000$ to examine the African climate during the last ice age." 84

The administrator's burden is the positive one of justifying the gift or grant. The distinction is significant. A letter written by Albert Szent-Gyorgyi in 1972 about the processes of discovery contrasts the appollonian researcher tending to develop established lines of research as against the Dionysian, who relies on intuition. Szent-Gyorgyi remarks: ${ }^{\mathbf{8 5}}$

A discovery must be, by definition, at variance with existing knowledge. During my lifetime, I made two. Both were rejected of fhand by the popes of the field. Had I predicted these discoveries in my applications, and had those authorities been my judges, it is evident what their decisions would have been.

The positive case for decentralized decision-making has to be understood. At various times in French history the French Minister of Education has been able to look at his watch and advise his visitor the precise lesson being taught at that time in every classroom in a stated grade throughout the republic. Of course, in one sense, this practice leads to great efficiency. Text books, procedure, examinations, can all be identical but, at the same time, any omission or error will be multiplied time and time over. The intellectual history of the race long ago taught that no group of men, however well-motivated and wise, could

83. Id. at 43

84. Chicago Sun Times, Mar. 12, 1975, at 2, col. 2. See also Wall Street Journal, Mar. 7, 1975, at 1, col. 5 .

85. Szent-Gyorgyi, Dionysians and Appollonians, 176 SCIENCE 966 (1972). 
make all appropriate decisions. The pluralism and multiplicity of decisionmaking promotes the diversity which is one of the great strengths of the American system of higher education.

The euphony of the tax theologian in search of equity may well be abstractly pleasing but destruction and injury to colleges and universities, even if conducted in the name of populism or anti-elitism, would be devastating to the quality of national life. Our system of higher education has flourished in an atmosphere where tax laws lend encouragement to charitable giving and the costs to this system would greatly exceed any benefits which would be achieved for our tax system should this atmosphere be made hostile to charitable gifts. 